\title{
Värdet av ett klassbegrepp
}

\section{Mikael Stigendal}

SAMMANDRAG: Under klassanalysens storhetstid 1970-1985 var alla klassbegrepp förankrade i Marx' värdeteori. Det gjordes dock efter hand olika tolkningar av värdeteorin och därmed uppstod två huvudspår i utvecklingen av klassbegreppet. De som företrädde den tolkning som kallades arbetsvärdeteorin övergav efterhand värdeteorin och utvecklade ett klassbegrepp med fokus på det människor har, inte på vad de gör. Det har kommit att bli den dominerande definitionen av klassbegreppet. I sin artikel vill Mikael Stigendal istället visa på bruksvärdet av det andra huvudspårets klassbegrepp, det som håller fast vid Marx’ värdeteori men utifrån en annan tolkning. Bara ett sådant klassbegrepp kan tillgodose det stora behov som finns av en klassanalys som inte bara kategoriserar människor utan därigenom också säger något om samhällets ekonomiska drivkrafter, vad människor kan förväntas göra och vad detta kan förväntas göra med dem, och då utifrån en fokusering på vad människor gör, särskilt i förhållande till produktionen och tillägnandet av mervärdet.

NYCKELORD: klass; klassanalys; klassbegrepp; värdeteori; kritisk realism; Karl Marx.

PUBLICERINGSHISTORIK: Originalpublicering.

MIKAEL STIGENDAL är professor i sociologi vid Malmö universitet.

E-POSTADRESS: mikael.stigendal@mau.se

FÖRSLAG PÅ KÄLLANGIVELSE:

Stigendal, Mikael (202I) "Värdet av ett klassbegrepp", i Arkiv. Tidskrift för samhällsanalys, nr I3, s. II-50. https://doi.org/IO.I3068/2000-62I7.I3.I

(C) Mikael Stigendal/Arkiv förlag \& tidskrift 2O2I (publicerad 20 maj 202I)

Artikeln distribueras enligt en upphovsrättslicens från Creative Commons: erkännande, icke-kommersiell, inga bearbetningar, som medger icke-kommersiell användning och spridning i oförändrat skick så länge källan anges. 
Arkiv. Tidskrift för samhällsanalys är en sakkunniggranskad vetenskaplig tidskrift för samhällsvetenskap och historia. Samtliga artiklar publiceras fritt tillgängliga på:

www.tidskriftenarkiv.se

Beständig länk: https://doi.org/I0.13068/2000-62I7

Den här artikeln finns tillgänglig i följande format:

PDF: via beständig länk, https://doi.org/IO.I3068/2000-62I7.I3.I

TRYCK: ingår i bokutgåva av numret, ISBN: 978 9I 79243586

Grafisk utformning och sidnumrering är identisk i pdf och tryck.

Samtliga artiklar i nr I3 (202I) nås via beständig länk, https://doi.org/IO.I3068/2000-62I7.I3

Arkiv. Tidskrift för sambällsanalys

ISSN: 2000-62I7 (för elektronisk resurs)

ISSN: 2000-6225 (för tryckta nummer)

ges ut av

Stiftelsen Arkiv för främjande och spridning av samhällsvetenskaplig och historisk forskning

genom

Arkiv förlag \& tidskrift

Box 1559

SE-22I OI Lund

BESÖK: L Gråbrödersg 3 c, ipg

TEL: 046-I3 3920

ARKIV FÖRLAG: arkiv@arkiv.nu·www.arkiv.nu

TIDSKRIFTEN ARKIV: red@tidskriftenarkiv.se.www.tidskriftenarkiv.se

ANSVARIg UTGIVARE \& CHEFREDAKTÖR: Sven Hort

Administrativ Redaktör: David Lindberg

ReDAKTörer: Per Dannefjord, Lisa Kings, Zhanna Kravchenko, Anna-Maria Sarstrand Marekovic 


\title{
Värdet av ett klassbegrepp
}

\author{
MIKAEL STIGENDAL
}

\section{Inledning}

Har klassbegreppet blivit värdelöst? I en mening har det faktiskt blivit det. Det har nämligen förlorat sin tidigare så självklara förankring i värdeteorin. Som jag ska visa i denna artikel har det fått stora konsekvenser för klassanalysen. Ett första steg på vägen i den riktningen togs av Erik Olin Wright, den amerikanske sociolog som på 1970-talet lanserade storskaliga surveyundersökningar om klass, men som också gjorde sig känd genom sin kritik mot en av den tidens teoretiska giganter, den grekiske marxisten Nicos Poulantzas (Wright 1977).

Wright gick i sitt alternativ förbi den företeelse som enligt en ledare i tidskriften Zenit utgjorde "själva livsnerven i kapitalismen", nämligen mervärdet (Wright I977, s. 4). Marx’ otvetydiga formuleringar om produktionen och tillägnelsen av mervärdet var ändå den minsta gemensamma nämnaren för klassanalyser under det som har kallats klassanalysens storhetstid. Den pågick under 1970-talet och fram till mitten av I980-talet (Therborn I983a, s. 39). Till de ledande forskarna hörde Harry Braverman, Nicos Poulantzas och Erik Olin Wright, samt på hemmaplan Göran Therborn och lite senare Göran Ahrne.

Vad av allt detta har levt vidare in i vår tid? Vad och vem hänvisar forskarna till i 20I7-I8 års svenska klassprojekt, det som har resulterat i den omfattande antologin Klass i Sverige (Suhonen et al. 202I)? Ja, inte 
är det Braverman eller Poulantzas. Med något undantag är det inte heller Therborn. Den förebild som flest nämner är Erik Olin Wright, den forskare som på 1970-talet utmönstrade mervärdet och 25 år senare kapade förankringen helt i värdeteorin (Wright 2015).

Min artikel handlar om just detta, nämligen kopplingen mellan klassbegreppet och värdeteorin. Utifrån förklaringar av vad värde är i avsnitt 2 och klassbegreppets beroende av värdeteori i avsnitt 3 ska jag visa hur det uppstod två olika spår i definitionen av klass, vilka utkristalliserade sig med avseende på just värdeteorin. Wright är den kanske mest framstående företrädaren för det ena spåret och det kommer att framgå av avsnitt 4. Det kännetecknas framför allt av den kapade förankringen i värdeteorin. Genom att analysera texter av Wright och hans efterföljare ska jag visa vad detta har fått för konsekvenser för klassanalysen.

Det andra spåret, vilket jag ägnar avsnitt 5 åt, kännetecknas tvärtom av att förankringen har utvecklats men utifrån en förändrad tolkning av Marx’ värdeteori och inte den tolkning som kallades arbetsvärdeteorin. Jag uppfattar det som att Göran Therborn företrädde detta andra spår under klassanalysens storhetstid. På senare år tycks han dock ha närmat sig det första spåret. För att tydliggöra skillnaderna mellan de två spåren är det därför särskilt intressant att jämföra hans senaste bok om klass från 2018 med den som publicerades 198I. Det ska jag göra utifrån analyser av dessa böcker i avsnitt 6 respektive 7 .

Det leder fram till mitt eget förslag på klassbegrepp och det handlar avsnitt $8 \mathrm{om}$. För att dess förtjänster ska kunna framhållas måste frågan ställas om vad det finns för behov av ett klassbegrepp. Det klassbegrepp som kan tillgodose detta behov och således bli användbart i en klassanalys av dagens samhälle måste utgöra, med Marx ord, en "rik totalitet med många bestämningar". I avslutningen ska jag sammanfatta detta klassbegrepp, men också ge några exempel på vilka klassanalyser det kan möjliggöra. 


\section{Värde, bland annat av ett klassbegrepp}

Marx skiljer mellan tre värdebegrepp; bruks- och bytesvärde samt värde (även kallat arbetsvärde). Samtliga tre härstammar från föregångarna inom den politiska ekonomin, Adam Smith och David Ricardo (Stigendal 20IO). Bruksvärdet är det materiella innehåll som gör köparen intresserad av att köpa varan. Den går att bruka till något. Dess bruksvärde beror på relationen mellan köparens behov och varans materiella egenskaper. Avgörande för dess storlek är hur väl den tillgodoser behovet. Bruksvärdet ger uttryck för en kvalitet, vilken kan vara svår att kvantifiera.

Bruksvärden behöver dock inte nödvändigtvis inhandlas på en marknad. Allt som motsvarar ett behov har ett bruksvärde. Det gäller även klassbegreppet men då måste vi också reda ut vad det ska fylla för behov. Det ska jag göra i avsnitt 8 . Ett bruksvärde behöver nämligen inte vara konkret och möjligt att peka ut. Ta till exempel den kunskap som eleverna lär sig i skolan. Den har ett bruksvärde. Ungdomar har behov av att lära sig och det ska de få göra i skolan. Vad de ska lära sig står i läro- och kursplaner. Därmed inte sagt att de verkligen lär sig det som står just där. De lär sig säkert också annat och även det kan ha ett bruksvärde. I vilken utsträckning eleven har lärt sig just det som står i läro- och kursplaner bedöms av läraren. Det kallas betyg och är tänkt att motsvara storleken på det bruksvärde som eleven har skaffat sig. Ett högt betyg ska innebära att eleven har skaffat sig mycket av det bruksvärde som hen enligt lärooch kursplanerna har behov av.

Betygen har dock också kommit att fungera som den andra formen av värde, bytesvärde. Genom betygen kan eleverna jämföras. De kan också jämföra sig själva med varandra. Det kan återverka på bruksvärdet och få studierna att inriktas på den kunskap som möjliggör ett bättre betyg (Allelin 20I9, s. 88). Ofta blir det faktakunskapen eftersom den kan vara lättare för läraren att bedöma, särskilt om de är stressade (Liedman 20II). I tider när stor vikt läggs vid betygen tenderar de att bli en form som lärandet stöps i. ${ }^{I}$ Det innehåll som inte platsar i denna form

I. Vad detta innebär vidareutvecklar jag i avsnitten nedan om kritisk realism (avsnitt 5) och om struktur och aktör (avsnitt 8). 
tenderar att falla utanför. De pluggar för att få bra betyg, brukar det heta. Det får eleverna att $\mathrm{i}$ allt högre grad framstå som varor. Med ett annat ord så varufieras de. Det är egentligen inget konstigt. I själva verket är det ett av syftena med skolan att inte bara producera utan också varufiera den arbetskraft som sitter lite här och var i kroppen och som eleven äger. Det tydliggörs också när betyget längre fram omsätts i lön. ${ }^{2}$

Bytesvärdet är den form som kostnaden för en vara kommer till uttryck i. Det är en viss kvantitet. Det är bytesvärdet som gör det intressant för ägaren att sälja bruksvärdet och därmed omvandla det till vara. Genom bytesvärdet, i form av vad den kostar i pengar, står varan i relation till andra varor på marknaden. Marx kallar därför bytesvärdet för varans samhälleliga form, till skillnad från bruksvärdet som utgör dess materiella innehåll. Som bytesvärden är skillnaden mellan olika varor kvantitativ. Det växlar också ständigt med tid och plats. Bytesvärdet möjliggör en jämförelse mellan ett paket smör och en liter mjölk. Samma jämförelse går inte att göra mellan varornas bruksvärden. Smör är smör och mjölk är mjölk. Skillnaden är kvalitativ.

Om vi däremot pekar ut något som de har gemensamt kan även smör och mjölk jämföras. Det kan till exempel vara fetthalt. Bytesvärdet bestäms dock inte av fetthalten och även om prisskillnaden mellan just smör och mjölk berodde på fetthalten så skulle det inte förklara priset för till exempel en mobiltelefon. Smöret, mjölken och mobiltelefonen måste ha något annat gemensamt som gör dem jämförbara.

Enligt Adam Smith, den moderna nationalekonomins centralgestalt, är detta gemensamma det objektiverade och materialiserade arbetet. Med det menade han den mängd arbete som har krävts för att producera en vara och som finns materialiserad i den. Denna arbetsmängd kallar Smith rätt och slätt för värde. Jag ska kalla det arbetsvärde för att det inte ska förväxlas med bytesvärde. Arbetsvärde och bytesvärde är nämligen inte samma sak. Pengar och varor, säger Smith, "innehåller värdet av en viss mängd arbete som vi byter mot vad som för närvarande antas innehålla värdet av en lika stor mängd” (Smith 2008, s. 36). Enligt Smith är det därför också arbetsvärdet som bestämmer bytesvärdet, det vill säga vad varan kostar. Bytesvärdet kan visserligen variera beroende

2. Jag utvecklar detta vidare i avsnittet om regleringsteorin (avsnitt 5). 
på utbud och efterfrågan, men variationerna sker runt arbetsvärdet, "det centrala pris, mot vilket alla varors pris kontinuerligt dras" (Smith 2008, s. 56).

Det innebär dock inte att en långsam arbetare skapar ett högre arbetsvärde än en snabb. Det är inte bara den enskilde producentens arbetstid som bestämmer varans arbetsvärde utan det utgör ett genomsnitt av den tid det tar att producera den; den samhälleligt genomsnittliga arbetstiden. Storleken på detta genomsnitt bestäms genom bytet på marknaden. Om det sedan har tagit den enskilde kortare tid att producera varan så är det till dennes fördel. Då kan hen göra en vinst på denna skillnad eller kanske öka sin konkurrenskraft genom att sälja varan till ett pris som är lägre än dess arbetsvärde. Om varan har tagit längre tid att producera än det samhälleliga genomsnittet är det till hens motsvarande nackdel. Då kanske vederbörande bör se sig om efter ett annat arbete.

\section{Klassbegreppets beroende av en värdeteori}

Detta kom att kallas arbetsvärdeteorin (labour theory of value) och i den ingår också en förklaring till varifrån vinster i en kapitalistisk ekonomi härstammar. Vinster kan visserligen uppstå på många sätt, till exempel genom köp och försäljning av bostäder. Om priserna fortsätter att stiga kan den som köper idag göra en vinst genom att sälja i morgon. Historien har dock visat att det inte fungerar i evighet. Det kommer en dag då priserna sjunker. Den enes vinst blir då den andres förlust. Det kallas spekulation och utgör ett nollsummespel. Så länge varor köps och säljs i enlighet med sina arbetsvärden och detta naturliga pris således överensstämmer med marknadspriset, kan inga sådana spekulationsvinster göras.

Det finns dock en källa till vinst som inte ingår i nollsummespelet och inte behöver betalas i morgon. Smith menar att den härstammar från bytet mellan lönearbete och kapital. Han kallar lönearbete för "labour commanded", till skillnad från det "embodied labour" som finns objektiverat i den producerade varan. Kapitalisten köper "labour commanded" men betalar med det "embodied labour" som finns objektiverat i pengarna. Smith var därigenom en förklaring av vinsten på spåren 
men lyckades inte precisera dess ursprung. För detta blev han kritiserad av sin efterföljare David Ricardo men det var Marx som tog det avgörande steget.

Det tog han genom att lokalisera vinsten i en kapitalistisk verksamhet till skillnaden mellan å ena sidan arbetsvärdet av lönearbetarens arbetskraft och å andra sidan det arbetsvärde som lönearbetaren producerar. Karakteristiskt för arbetskraften är nämligen just att den kan producera arbetsvärde. Det kan ingen annan vara. Det är kapitalistens stora lycka att hen på marknaden upptäcker en vara, "vars själva bruksvärde har den egendomliga beskaffenheten att vara en källa till värde, vars verkliga förbrukning alltså själv är objektivering av arbete och därmed värdeskapande" (Marx 20I8a, s. I44).

I den utsträckning det arbetsvärde som lönearbetaren producerar är större än arbetsvärdet av lönearbetarens arbetskraft uppstår det ett mervärde. Helt i enlighet med utbytets lagar tillfaller det kapitalisten. Lika värden byts mot varandra. Som Marx skriver är det "en speciell fördel för köparen men alls ingen orätt mot säljaren” (Marx 20I8a, s. I67).

Det merarbete som mervärdet grundar sig på är dock i sig inget karakteristiskt för kapitalismen. Det har förekommit i alla tider. Det speciella med kapitalismen är den form som merarbetet tar sig, nämligen som produktion av mervärde. I kapitalismen går det inte att direkt tillägna sig merarbetet och dess resultat. Den som säljer sin arbetskraft gör det av fri vilja, åtminstone formellt sett, och tvingas därför inte att skapa merarbete. För att merarbetet ska kunna förverkligas och kapitalisten tillägna sig det måste produkten av merarbetet sedan också säljas och därmed förvandlas till pengar (Elson I979, s. II5-II6).

Därmed kan det se ut som om vinsten härstammar från pengarna. Pengar tycks äga en mystisk förmåga att generera vinster. Men det beror på att de materialiserar och innehåller ett mervärde; det vill säga en skillnad mellan arbetsvärdet av arbetskraften och det arbetsvärde som skapas i produktionen. Det är detta som gör pengarna till kapital - men inte bara pengarna. Även de verktyg och råmaterial som används blir till kapital. Det gäller dessutom lönearbetarna. Den arbetskraft som har sålts till kapitalisten blir också till kapital, men just under den tid som kapitalisten har köpt arbetskraften. I praktiken innebär det att de egent- 
liga ägarna av arbetskraften, lönearbetarna, ingår i produktionsprocessen och det får sina konsekvenser för dem, vilket jag ska återkomma till.

Detta gör kapitalet särskilt viktigt att analysera. Det innebär nämligen att kapitalet inte bara består av objektiverat och dött arbete i form av till exempel pengar, lokaler, maskiner, verktyg och råmaterial. Det består också av människor, nämligen de som har sålt sin arbetskraft, vilken kapitalet under en viss tid har skaffat sig rätten att använda. Vinster i en kapitalistisk ekonomi härstammar i grunden från denna relation mellan lönearbete och kapital. Det är innebörden av den definition av kapital som Marx utvecklade. Som Marx skriver är kapitalet "inte ett ting, utan ett genom ting förmedlat förhållande mellan människor" (Marx 20I8a, s. 673). Arbetskraften är den enda källan till nytt arbetsvärde och därmed till det mervärde som vinsten grundar sig på. Endast de kapital som innehåller levande arbete och producerar mervärde kan kallas produktiva (Sum \& Jessop 2013, s. II7).

Det marxistiska klassbegreppet tar sin utgångspunkt i denna definition av kapital som en social relation, genom vilken fria individer säljer sin arbetskraft för en viss tid till köpare som får rätten att utnyttja denna arbetskraft till att producera varor och i första hand ett mervärde. Kapitalets sociala relation är således både en bytes- och produktionsrelation. Definierad på detta sätt så polariserar kapitalet samhället i två olika klasser, kapitalister och arbetare (Aglietta 1987, s. 46).

Som kapitalister räknas de som köper lönearbetarens arbetskraft och ser till så att den används för att i första hand producera mervärden. Arbetarklassen består i sin tur av dem som säljer sin arbetskraft. Som bärare av den arbetskraft som kapitalet köper är lönearbetaren en aktör. Det är dock ett mycket säreget aktörskap, eftersom kapitalet äger lönearbetarens arbetskraft så länge denne ingår i produktionsprocessen. Lönearbetaren producerar det mervärde som hela kapitalackumulationen beror på men framstår ändå som objekt.

Annat är det med kapitalets företrädare, de som personifierar kapitalet och därmed kan kallas kapitalister. De bidrar inte till produktionen av varken bruksvärde eller mervärde, men eftersom de bestämmer över produktionen av mervärde och detta överordnas allt annat framstår de som inte bara kapitalackumulationens utan hela utvecklingens subjekt. 
Kapitalets företrädare måste se till så att mervärdet produceras men också att det förverkligas genom försäljningen av de producerade varorna, vare sig det sker till en varukapitalist eller direkt till konsumenterna. Cirkulationen av penningen som kapital blir därmed ett självändamål, oavsett vad som produceras. "Som medveten representant för denna rörelse blir penningägaren kapitalist", skriver Marx (2018a, s. I32): "Det objektiva innehållet i denna cirkulation - värdeökningen - är hans subjektiva avsikt, och blott i den mån hans enda motiv är att ständigt öka rikedomen, uppträder han som kapitalist eller som personifierat kapital.”

\section{Värdeteorins ena spår}

Många av 1960- och 1970-talens marxister betraktade värdeteorin hos Marx som en direkt vidareutveckling från Smith och Ricardo. Syftet ansågs framför allt vara att förklara priser, det vill säga vad olika varor kostar. Med den utgångspunkten gjorde en av de mest kända marxistiska ekonomerna, Maurice Dobb, en indelning i två typer av teorier; produktions- respektive marknadsförklaringar av priser (Elson 1979).

Enligt den ena typen av teori bestäms kostnaden för en vara, dess pris, av produktionen och den mängd arbete som ingår i varan. Arbetsvärde likställs enligt denna teori med arbetsmängd och det anses vara bestämt oberoende av priser och det som händer på marknaden. Priserna kan visserligen variera, så som Smith menade (se ovan), men de utgör bara uttryck för arbetsvärdena och bidrar inte till bestämningen av dem. Enligt den andra typen av teori bestäms priser av utbud och efterfrågan på marknaden. Det som händer i produktionen blir ointressant och begreppet arbetsvärde avvisas. Till den ena gruppen teoretiker, företrädarna för arbetsvärdeteorin, räknades Smith, Ricardo och Marx, medan de neoklassiska nationalekonomerna från 1870-talet och framåt ingick i den andra gruppen (Elson 1979, s. II6-I2I).

Arbetsvärdeteorin var viktig för 1970-talets Erik Olin Wright. Det framgår bland annat av en artikel som han skrev i New Left Review 1979, "The Value Controversy and Social Research". Wright ville där ta ner teorierna på jorden. Det framhålls som det centrala syftet med artikeln. Han ville ta reda på hur arbetsvärdeteorin kan vara till hjälp i empiriska 
undersökningar. Wright föreslog visserligen en vidareutveckling med syftet att möjliggöra "en teori om de systematiska kopplingarna mellan klasstruktur, klasskamp och vinster" (Wright 1979, s. 64). För Wright rådde det dock vid denna tid ingen tvekan om att sådana undersökningar måste grunda sig på arbetsvärdeteorin.

Vad var det då för klassbegrepp som möjliggjordes? I likhet med sina samtida marxister definierar Wright klasserna utifrån deras positioner i produktionsförhållandena: "Den avgörande aspekten av dessa produktionsförhållanden handlar om förmågan hos en klass att tvinga en annan klass - de direkta producenterna - att utföra arbete utöver vad som behövs för reproduktionen av de direkta producenterna själva och att tillägna sig produkterna av detta 'merarbete”" (Wright 1979, s. 65). Lägg märke till termen "förmåga". Den är central.

Wright definierar nämligen inte klasserna utifrån vad de gör utan utifrån vad de har. Nyckelkriteriet är kontroll (Wright 1979, s. 75). Det är således inte produktionen respektive tillägnandet av arbetsvärde i sig som får honom att definiera vissa som arbetare och andra som kapitalister. Det är inte processen utan dess förutsättningar som Wright fokuserar på. Han talar visserligen om värde och kapital men bryter "faktiskt konsekvent klassanalysens beroende av en kapitalistisk ekonomi", som Therborn skriver i en artikel från 1983 (Therborn 1983a, s. 40).

Den som kom att företräda Wrights klassbegrepp i Sverige var Göran Ahrne. I en surveyundersökning som gjordes på hösten 1980 använde sig Ahrne av frågor som hade utarbetats av Wright, "för att kunna tilllämpas på den klassmodell som Wright presenterade utifrån kritiken av Poulantzas" (Ahrne et al. 1985, s. 37). Marx var den självklara utgångspunkten även för Ahrne och i linje med Wrights utveckling av klassbegreppet angavs makt och kontroll som avgörande kriterier i definitionen av klasserna. Värdebegreppet användes dock inte i bestämningen av klasserna.

Det fanns dock med i kapitel 5, skrivet av Ahrne och Håkon Leiulfsrud, för att klargöra skillnaden mellan kapitalism och statlig verksamhet. Där framgick det att "den grundläggande värdeskapande processen i samhället sker i den kapitalistiska produktionen" och "detta kapitalförhållande" står de offentligt anställda utanför. Författarna såg det som ett 
problem "att man alltför lätt slår ihop skikt inom den offentliga sektorn, som har skilda objektiva villkor i fråga om inkomst, makt och arbetsförhållanden och därmed också skilda intressen och politiska förutsättningar”. Uppdelningen mellan privat och offentligt anställda såg de därför som viktig att hålla fast vid, det vill säga skillnaden "mellan anställda som utför merarbete som bestäms direkt genom beslut som styrs av kapitalets ackumuleringsprinciper å ena sidan och mellan anställda som utför arbete som bestäms genom politiska beslut i demokratiskt valda styrelser å andra sidan” (Ahrne et al. 1985, s. 58-60).

Författarnas uppdelning i privat och offentligt anställda byggde uppenbarligen på en uppfattning om arbetsvärdets betydelse men det användes inte för att kategorisera de privatanställda i klasser. I en fotnot nämndes begreppet produktionssätt men när det definierades sades det ingenting om värde. Värdebegreppet fanns uppenbarligen med i bilden men det var nog inte så viktigt. Och det var väl också därför som det snart försvann helt och hållet, för så blev det.

Drygt 25 år efter artikeln i New Left Review var Wright den som fick förtroendet att skriva om "social class" i Encyclopedia of Social Theory. Där avfärdade han arbetsvärdeteorin och menade att den "aldrig varit särskilt framträdande, inte ens bland sociologer som arbetar i den marxistiska traditionen. Och i vilket fall beror begreppet exploatering och dess relevans för klassanalysen inte på arbetsvärdeteorin” (Ritzer 2005, s. 72I). Hans eget sofistikerade försök att vidareutveckla arbetsvärdeteorin hade förpassats till historiens skräphög. Han hade kommit fram till att det inte behövdes. Och den slutsatsen var han inte ensam om.

Den indelning som Maurice Dobb och andra gjorde mellan produktionsförklaringar och marknadsförklaringar bäddade för det problem som kom att kallas transformationsproblemet. Den samhälleligt nödvändiga arbetstid som objektiveras och materialiseras i varan, det vill säga dess arbetsvärde, betraktades som något separat från marknaden. Arbetsvärdena ansågs kunna beräknas oberoende av priserna. Som Dobb hävdade kunde "bytesrelationer eller 'marknadsframträdanden' bara förstås [...] om de uppfattades som uttryck för dessa mer fundamentala relationer" (Elson 1979, s. II8). Därmed gjorde man Marx till en matematisk ekonom, jämförbar med de neoklassiska nationalekonomerna. 
Det fick många att uppleva det som att vägen vidare bar ut i öknen och då övergav man istället marxismen.

Det gjorde dock ändå inte Wright. Till skillnad från kollegorna, bland annat G. A. Cohen och Adam Przeworski, i den grupp som han hade anslutit sig till 1979, kallad "Analytical Marxists", tog Wright inte avstånd från marxismen (Burawoy 2020, s. 82). Han höll konsekvent fast vid såväl marxismen som sin resursbaserade definition av klass. Det visade sig funka ganska väl. Wright kunde därigenom operationalisera begreppen och på den grunden genomföra stora empiriska undersökningar. Han tog därmed udden av den kritik som hade funnits mot marxismen som någonting esoteriskt. Enligt Burawoy såg han kvantitativa undersökningar som ett sätt att legitimera marxismen inom sociologin, ja rentav visa marxismens överlägsenhet som vetenskap. Det tog dock samtidigt udden av marxismen (Burawoy 2020, s. 74, 79).

Göran Ahrne har också hållit fast vid den resursbaserade definitionen av klass. Det framgår av den rapport som han, Niels Stöber och Max Thaning har skrivit till klassprojektet (Ahrne et al. 20I8). När de ska svara på frågan "Vad är klass?”, tillika namnet på ett avsnitt i deras rapport, finns det inte ett spår av några värden. Kärnan i förståelsen av klasssamhället sägs vara arbetets organisering och makten över arbetet. Tre grundläggande maktdimensioner, härstammandes från Wright, används i beskrivningen av klasstrukturen; ägande, auktoritet och expertkunskaper. Klasskillnaderna förknippas med skillnader i inkomst. Överlag är det resurser det handlar om, förutom inkomst även till exempel fysisk styrka. Med andra ord så bygger klassindelningen på det som människor har, inte på det som de gör.

Uppdelningen mellan privat och offentligt anställda görs även i denna aktuella rapport, men dess tidigare grund saknas. I boken från 1985 drog man gränsen utifrån värdebegreppet, åtminstone implicit, men det har nu helt förlorat sin betydelse. Därmed har klassbegreppet trubbats av och dess förklaringskraft försvagats. Hur ska man då kunna förklara till exempel varför en majoritet av befolkningen är emot vinster i välfärden? Och hur ska man kunna förklara varför New Public Management har funkat så dåligt i offentlig sektor? 


\section{Värdeteorins andra spår}

I tolkningen av den marxistiska värdeteori som låg till grund för klassanalysen under dess storhetstid uppstod det också ett annat spår. Samma år som Wright (1979) publicerade Diane Elson en artikel med titeln ”The Value theory of Labour". Där förde hon fram en annan tolkning av värdeteorin. Enligt Elson syftar inte värdeteorin hos Marx i första hand till att förklara priser. Marx fullföljer inte Smiths och Ricardos arbetsvärdeteori utan bryter med den, menar hon. Det gör han genom att byta förklaringsobjekt, det vill säga det som ska förklaras. Objektet för Marx’ värdeteori är inte priser, enligt Elson, utan arbete (1979, s. I23):

Det handlar inte om att söka en förklaring till varför priserna är vad de är och hitta den i arbetskraft utan snarare att söka förståelse av varför arbetskraften tar de former den gör och vilka politiska konsekvenser det har.

Enligt denna tolkning fastställs inte storleken på arbetsvärdena i varuproduktionen, avskilt från varucirkulationen på marknaden. Den samhälleligt genomsnittliga arbetstid det tar att producera en viss vara, det vill säga dess arbetsvärde, fastställs genom konkurrensen på marknaden men under förutsättning att varan har producerats av lönearbetare i många olika företag som konkurrerar med varandra. Arbetsvärdet kan dock inte beräknas direkt i arbetstid, vilket företrädarna för arbetsvärdeteorin hävdade. Det samhälleliga genomsnittet är ingen färdig förutsättning utan ett framväxande och föränderligt resultat (Elson 1979, s. I35-136). Den arbetstid som kan mätas direkt i timmar, oberoende av pris, är särskilda individers särskilda arbetstid, inte den abstrakta tid som utgör det samhälleliga genomsnittet.

Arbetsvärdet kan bara komma till uttryck i varans pris, det vill säga dess bytesvärde. Endast pengar och inte arbetstid kan fungera som den sociala måttstocken. Det är dock i grunden inte pengar som gör varorna jämförbara. De är jämförbara enbart i den utsträckning de innehåller arbetsvärde, producerat av det som Marx kallar abstrakt arbete, det vill säga förbrukning av arbete i allmänhet. Som uttrycksform för arbetsvärdet återverkar dock priset med en tvingande kraft på lönearbetarnas konkreta arbete. Denna tvingande kraft skapar lönearbetarna själva, dock 
utan att veta om det. Det beror på att de inte bara utför konkret arbete utan också abstrakt arbete. Det abstrakta arbetet har de dock ingen kontroll över och det låter sig som sagt inte mätas i tid utan kan bara fastställas i efterhand genom konkurrensen på marknaden och då i pengar. Objektiveringen av det abstrakta arbetet får dock högst påtagliga effekter för lönearbetaren. Det kan ta sig uttryck i krav på till exempel standardiserade rörelser och utbytbarhet. Det gör sig gällande som en reglerande naturlag, ungefär som tyngdlagen. Det är framför allt detta som Marx’ värdeteori handlar om, menar Elson. Därför vill hon inte kalla den en "labour theory of value" utan en "value theory of labour".

\section{En kritisk realism}

Jag uppfattar Elson som en tidig företrädare av kritisk realism, det vill säga den vetenskapsfilosofi som utgör en tredje ståndpunkt vid sidan om huvudalternativen positivism och socialkonstruktivism (se t ex Danermark et al. 20I8). För kritisk realism är avståndet mellan verkligheten och kunskapen om den oöverstigligt. Det hindrar dock inte att såväl verkligheten som kunskapen om den kan vara orsaker till en viss händelse. Så ser varken positivismen eller socialkonstruktivismen på det. Positivismen uppfattar kunskapen som en återspegling av verkligheten. Socialkonstruktivismen reducerar tvärtom verkligheten till kunskapen om den.

Därmed ger både positivism och socialkonstruktivism uttryck för antaganden om verkligheten. Det är bara det att båda tar sina antaganden för givna och gör ingen särskild poäng av det. Kritisk realism framhåller tvärtom beroendet av sådana antaganden och gör dem dessutom till föremål för reflektion. Det har lett till skapande av en innehållsrik uppsättning antaganden om verkligheten, det vill säga en ontologi. Till det viktiga i denna ontologi hör distinktionen mellan det som synes vara (det empiriska), underliggande potentialer (det reella) och aktualiseringen av dessa (det aktuella) (Jessop 2005, s. 42). Just denna tankefigur förekommer i Elsons artikel.

Elsons kritiska realism visar sig i hennes ifrågasättande av den dominerande synen på kausalitet. Enligt henne ska inte värdeteorin hos Marx förstås som en förklaring av samband mellan förutbestämda och obero- 
ende variabler inom produktionen och beroende variabler inom cirkulationen (Elson I979, s. I30). Elson nämner visserligen inte den engelske I700-talsfilosofen David Hume i sin artikel men den syn på kausalitet som hon kritiserar har blivit förknippad med honom och ligger även till grund för till exempel positivismen. Enligt Humes klassiska lag om orsakssamband kan A pekas ut som orsak till B om, för det första, A och B berör varandra $\mathrm{i}$ tid och rum, för det andra, B följer efter $\mathrm{A}$ i tiden, samt för det tredje, B endast uppstår på grund av A (Se t ex Brante 1997, s. 3I7). Denna lag får oss att lägga särskild vikt vid det synbara, det som empiriskt kan fastställas.

I Marx texter kan däremot samma fenomen finnas med som både bestämmande och bestämt objekt, det vill säga som både orsak och verkan. Objekten framställs inte som externa i förhållande till varandra utan interna. För att ta ett konkret exempel så passar en fotbollsspelare inte bollen oberoende av var motståndarna befinner sig på planen. De två lagen är inte externa i förhållande till varandra. Motståndaren är både bestämmande och bestämd av hur bollen spelas. I passningsögonblicket sker därmed orsak och verkan samtidigt, helt i strid med Humes klassiska lag. Det blir tydligt också när målvakten försöker påverka och psyka den skytt som slår en straff. Om matchen överhuvudtaget ska kunna spelas måste det ske i en gemensam form och det formar samtidigt spelet, precis som språket gör när vi pratar med varandra och utan något slags gemensamt språk (inbegripet även kroppsspråk) kan vi knappast prata med varandra. Med Elsons ord medför detta "en syn på världen som ett kvalitativt föränderligt kontinuum, inte en sammansättning av diskret distinkta former" (1979, s. I40).

Det Elson framhåller är vikten av att uppfatta verkligheten som process, inte som ett fast tillstånd. Verkligheten kan sägas bestå av formbestämda processer. Jag ska återkomma till vad det innebär i avsnittet om struktur och aktör. Dock gav jag redan i avsnitt 2 uttryck för detta synsätt när jag beskrev hur betygen har kommit att bli en form som lärandet stöps i vilket leder till att eleverna varufieras.

Utifrån detta synsätt utvecklade Marx sina förklaringar i två faser, den första kallad analys och den andra syntes. Genom analysen tar vi oss "från det föreställda konkreta till det allt tunnare abstrakta", där begrep- 
pen är enkla och inte består av så många bestämningar. Genom syntesen färdas vi sedan tillbaka till det konkreta, men nu är vår föreställning inte längre kaotisk utan den har blivit "en rik totalitet med många bestämningar och relationer" (Marx \& Engels 1975, s. 35). Genom denna andra fas återkommer vi inte till utgångspunkten utan vi tar oss bortom den eftersom den möjliggör en förståelse av utgångspunkten i ett annat ljus (Elson 1979, s. I42).

Det innebär att vi inte kan ta för givet vad som är en orsak. Först måste vi analysera det potentiella, det som skulle kunna vara en orsak, och det kan vi göra på olika abstraktionsnivåer. Genom syntesen fastställer vi sedan hur dessa potentialer aktualiseras i sina konkreta sammanhang. Som Elson beskriver det innebär metoden en rörelse "i en allt vidare spiral, beaktandes fler och fler aspekter av den historiska process från vilken utgångspunkten gjordes till enskildhet och separerades” (I979, s. I43).

Elson nämner visserligen inte kritisk realism i sin artikel men det enda som egentligen saknas är just benämningen (the signifier). Artikeln ger nämligen uttryck för ett innehåll (the signified) som andra skulle kalla kritisk realism. Till det hör antagandet om en oberoende verklighet som genom att vi verkar i den gör oss till dem vi är även om vi kanske inte tänker så mycket på det. Denna verklighet kan dock också göras till föremål för ett kunskapande och kallas då referentobjektet. Kunskapen om detta referentobjekt kallas i sin tur referensobjekt (det vill säga med ett $s$ istället för $\mathrm{t}$ ), vilket består av såväl benämningar (signifiers) som det benämnda (signified), det vill säga namn på olika saker respektive det vi menar med dessa namn, till exempel definitioner av dem (Stigendal \& Novy 20I8). Till exempel är klass en benämning (signifier) men det förknippas också med något (signified) och det kan vi utveckla genom att göra det till ett begrepp. Utmärkande för kritisk realism är just distinktionen mellan signifier, signified och referent (Sum \& Jessop 2013, s. 24). För positivismen existerar bara signifier och referent medan verkligheten för socialkonstruktivismen endast består av signifiers och signifieds.

Elsons tolkning av värdeteorin bygger uppenbarligen på en annan vetenskapsfilosofi än den som de hon kritiserar ger uttryck för. Det är det som gör hennes kritik så grundläggande. Det är också därför det finns 
skäl att tala om detta som ett annat spår i tolkningen av värdeteorin. I denna mening kan också Marx betraktas som en kritisk realist, även om inte heller han använde benämningen (Jessop \& Sum 2006, s. 299). Den metod som Marx delar upp i analyser och synteser (se ovan), beskriven av Elson som en "allt vidare spiral", kallas inom kritisk realism för retroduktion (Elson I979, s. I29-I30).

Jag tolkar också Elson som en tidig företrädare av det som Anders Ramsay kallar marxforskningens fjärde fas (Ramsay 2008, s. 92). Ramsay framhåller Michael Heinrichs avhandling från I99I som centralt verk i denna färde fas. Precis som Elson uppfattar Heinrich det som att Marx med sin värdeteori bryter med föregångarna Smith och Ricardo (Heinrich 2008, 2013). Det som jag kallar värdeteorins ena spår karakteriserar Heinrich som en naturalistisk tolkning till skillnad från det andra spårets samhälleliga tolkning av värdeteorin. I den naturalistiska tolkningen utgör värdet något naturligt, en substans som varan innehåller. Den samhälleliga tolkningen uppfattar istället värde som en samhälleligt bestämd storhet.

Den samhälleliga tolkningen innebär att det inte har någon betydelse vad för slags bruksvärde som produceras för att det ska bli kapitalism. ${ }^{3}$ Allt lönearbete som producerar ett arbetsvärde större än arbetsvärdet av arbetskraften är produktivt, sett utifrån kapitalets intresse. Det kan vara kvalificerat eller okvalificerat arbete. Det kan gälla industriarbetare men också till exempel skådespelare, barnskötare eller lastbilschaufförer. Varans bruksvärde, färg, form och varaktighet har ingen som helst betydelse. Bara det finns någon som vill köpa den. Avgörande är att produktionen drivs enligt kapitalistiska principer, det vill säga i första hand syftar till att det ska skapas ett mervärde genom skillnaden mellan arbetsresultatets arbetsvärde och arbetsvärdet av arbetskraften.

\section{Regleringsteorin}

En liknande tolkning av värdeteorin utgjorde även grunden för regleringsteorin, det vill säga den skolbildning som också uppstod i slutet av I970-talet. Reglering gjordes till ett nyckelbegrepp av Michel Aglietta

3. Den uppfattningen hade även Wright (se 1977, s. I4), till skillnad från Poulantzas som menade att mervärde bara skapas i produktionen av fysiska ting. 
i A Theory of Capitalist Regulation (1987), ursprungligen publicerad på engelska 1979, det vill säga samma år som Elsons artikel. Regleringsteorin vände sig mot den neoklassiska nationalekonomin men udden var även riktad mot den tolkning av Marx som utvecklades på sextiotalet, förknippad med framför allt Louis Althusser, den som innebär att ekonomin reglerar sig själv, "i sista instans", som Althusser uttryckte det. Som Elson skriver i sin artikel gav han därmed också uttryck för den syn på kausalitet som hon kritiserar (Elson I979, s. I3I). Helt i linje med regleringsteorin avfärdar Elson tolkningar av "'regulate' i termer av en relation mellan en beroende och en oberoende variabel" (I979, s. I3I). Med inspiration från Aristoteles och Liedmans tolkning av honom uppfattar jag regleringarna som former vilka den ekonomiska verksamheten rör sig genom och som inte skulle existera utan den ekonomiska verksamhetens rörelse genom dem men som samtidigt bidrar till att göra ekonomin till det den är (Liedman 2006).

För regleringsteorins pionjärer i Paris var det minst lika viktigt att kritisera den althusserianska strukturmarxismen som den neoklassiska nationalekonomin, i väsentliga avseenden samma "teoretiska fiende", som Bob Jessop beskriver det: "[Eftersom] kapitalismen enbart genom marknadskrafterna inte kan säkra alla de förutsättningar som krävs för dess reproduktion så kan den inte utöva någon form av bestämning i sista instans över resten av den sociala formationen" (Jessop 2002, s. II).

Ett av skälen till detta är förekomsten av så kallade fiktiva varor. En av dessa fiktiva varor är arbetskraften. Den är inte som andra varor men används som om den vore det. Människan är inte skapad för att kunna sälja sin arbetskraft. Arbetskraften kan visserligen delvis sägas vara skapad av arbete, till exempel uppfostran och utbildning, men den går inte att bryta loss från en enskild människa och sälja vidare. Den går inte att lägga på lager. Ändå är det just arbetskraften som säljs och köps, som om den vore en vara. ${ }^{4}$

Den kapitalistiska ekonomins oförmåga att reproducera sig själv men också de motsättningar som ingår i kapitalets sociala relationer (i grunden mellan bruks- och bytesvärde) gör ackumulation av kapital högst problematisk, rentav osannolik och långt ifrån självklar. Jämvikt och ordning

4. I avsnitt 2 nämnde jag lite om hur betygen bidrar till varufieringen av arbetskraften. 
kan därför bara betraktas som ett högst osäkert resultat och inte som en självklar utgångspunkt. Att kapitalackumulationen faktiskt ändå lyckas, åtminstone periodvis, beror på regleringar, och i den betydelse som Elson klargör ovan. Ibland uppstår större helheter av olika regleringsformer och det kallar man för regleringssätt. Regleringsteorin skiljer mellan regleringarna och de former för jämvikt som en framgångsrik reglering resulterar i. Jämviktsformerna kallas för ackumulationsregimer.

Med hjälp av dessa begrepp möjliggör regleringsteorin en utveckling av klassbegreppet, dessutom på flera abstraktionsnivåer (Pijl 1984). På en hög abstraktionsnivå kan vi förstå hur ackumulation av kapital polariserar samhället i två olika klasser, kapitalister och arbetare. Det kan dock ske på olika sätt och det kan vi på en lägre abstraktionsnivå förstå med hjälp av begreppet ackumulationsregim.

Aglietta skiljer mellan två huvudtyper (Aglietta 1987, s. 7I). Den ena kallar han extensiv ackumulationsregim. I denna regim ökas vinsten genom förlängningar av arbetsdagen. Det innebär att kapitalisterna inte bryr sig så särskilt mycket om hur lönearbetarna har det, helt enkelt för att de inte har något intresse av deras efterfrågan. Den andra typen kallar Aglietta intensiv ackumulationsregim och i den ökas vinsten genom införandet av nya maskiner. En av de tidiga förespråkarna för denna ackumulationsregim var Henry Ford. Därför kom den att kallas fordism (Gramsci 197I).

Skillnaderna mellan dessa ackumulationsregimer har stor betydelse för formerandet av klasserna (Jessop 2002, s. 56). Fordismen ledde till ett helt nytt levnadssätt för de lönearbetande klasserna, eftersom hjulens fortsatta snurrande gjordes beroende av deras efterfrågan. Det är i denna övergång från extensiv till intensiv kapitalackumulationsregim som den generella välfärden har sin upprinnelse. Den intensiva ackumulationsregimen skapade betydligt gynnsammare förutsättningar för samförstånd än förlängningar av arbetsdagen. Tack vare en gemensam strävan efter höjd produktivitet kunde såväl löner som vinster stiga. Fordismen satte sin prägel på västvärldens ekonomier under efterkrigstidens första decennier och var särskilt framgångsrik i Sverige.

Som jag tolkar Therborns texter från början av 1980-talet så var han inne på det andra spåret i tolkningen av värdeteorin. I sin artikel från 
I983 om den nymarxistiska klassanalysens uppkomst och problem drog han slutsatsen att "klassanalysen skulle förlora mycket på att avlägsna sig från analyser av kapitalismens ekonomiska dynamik och på att inte använda grundläggande marxistiska verktyg för sådana analyser” (I983a, s. 4I). Det tycks ligga i linje med Elsons förslag. Den teoretiska grund som hon ger detta i en annan tolkning av värdeteorin nämns däremot inte av Therborn. Han anknyter dock till regleringsteorin och vill ställa "kapitalackumulationsprocesserna och de olika ackumulationsregimerna i centrum för en teoretisering kring och analys av klasserna" (I983a, s. 43). Jag uppfattar den tidens Göran Therborn som en företrädare för värdeteorins andra spår. Det gör hans klassanalys från 198I särskilt intressant. Och den ska nu därför nästa avsnitt ägnas åt.

\section{Therborns klassbegrepp från 198I i dagens ljus}

Enligt den definition som Therborn använder i sin bok Klasstrukturen $i$ Sverige 1930-1980 blir ett samhälle "delat i klasser (i marxistisk mening), när uppgifterna att utföra merarbete och att tillägna sig och bestämma användningen av merprodukten är skilda åt” (I98I, s. I5). Det är således i första hand inte vad människor har som motiverar indelningen av dem i klasser. Det är inte inkomster eller förmögenhet men inte heller till exempel utbildning eller hälsa. Therborns klassindelning grundar sig på det som människor gör, men inte vilket görande som helst utan det som gäller merarbetet. Den ena klassen består av dem som utför merarbetet, den andra av dem som tillägnar sig det och bestämmer hur det ska användas. Klassindelningarna är inga statiska beskrivningar, som Therborn säger, utan "knutna till en analys av samhällsutvecklingens drivkrafter och dynamik" (I98I, s. I3).

De som utför merarbetet ringar Therborn in i en särskild sektor som han kallar produktionssektorn, omväxlande även kallad produktionssfären. Det är en av fyra sfärer eller sektorer som Therborn delar in "samhällets institutionaliserade verksamheter" i. Det kan få en att uppfatta indelningen som sammanfallandes med olika typer av institutioner, till exempel industriföretag i en sektor och handelsföretag i en annan. Så är det dock inte riktigt tänkt. Indelningen är i första hand analytisk och 
därmed teoretiskt bestämd. Alla som till exempel arbetar i ett visst företag behöver inte ingå i samma sektor. Det uttalade syftet med indelningen är att befrämja en förståelse av hur ekonomiska förhållanden formar människors arbetsvillkor och sociala relationer (I98I, s. I7).

Produktionssektorn består av det produktiva arbetet, oavsett om det sker på ett industriföretag eller till exempel en speditionsfirma. Det är denna sektors viktigaste kännetecken. Det är därför den kallas produktionssektor. De producenter som ingår måste vara produktiva för kapitalet, det vill säga mervärdeproducerande. Är de inte det så kan de mycket väl producera något annat men de ingår inte i denna sektor. Under den tid som Therborn analyserar gällde det "behandlingen av produkter, deras uppfinnande, konstruerande, tillverkning, lagring och transporterande - samt ledningen och kontrollen av dessa arbeten" (I98I, s. I7).

De arbetare som ingår i dessa verksamheter och därmed producerar mervärde kallar Therborn för arbetarklass i snäv mening. De består av "de löntagare i den produktiva sfären som är anställda av kapitalägare, som inte har några maktbefogenheter delegerade till sig av arbetsgivaren och som inte har en anställnings- och arbetssituation som skiljer ut dem från massan av produktiva kroppsarbetare” (I98I, s. 27). Även lager- och transportarbetare räknas in. Flest arbetar inom industrin men många av de produktiva arbetarna är hantverkare och reparatörer, av bilar, cyklar, tv- och radioapparater. Byggnadsarbetarna är en annan stor grupp inom den produktiva arbetarklassen. "Industri- och byggnadsarbetare i företag av sådan storlek att kollektiva arbetsförhållanden och en relativt opersonlig relation till arbetsgivaren råder kan sägs utgöra arbetarklassens kärna" (I98I, s. 33).

Inga tjänsteproducerande verksamheter ingår och inte heller verksamheter förknippade med det som numera kallas vinster i välfärden. Det är inte så konstigt för de var ju alla anställda i offentlig sektor och inte mervärdeproducerande. Då. Men det är en allt större del av dem nu. Det visar hur definitionen i Therborns bok präglas av den tid som hans klassanalys gällde. Hur ska detta hanteras i vår tid? Det ska jag återkomma till.

Therborns produktionssektor består också, enligt citatet ovan, av "ledningen och kontrollen av dessa arbeten ..." (I98I, s. I7). Det rör 
sig om en stor grupp löntagare som inte kan räknas in i arbetarklassen. I karakteriseringen av dem tar han hjälp av Wrights begrepp "motsägelsefulla klasspositioner". Dessutom instämmer han i Wrights kritik av Poulantzas och vill inte som den sistnämnde föra ihop dem med småföretagarna som en "ny småborgerlighet". På grund av denna kategoris position mellan borgarklass och arbetarklass föreslår Therborn istället att de ska kallas mellanskikt. Det är en bred och mångfasetterad kategori. Den del av mellanskiktet som ingår i produktionssektorn och därmed bidrar till produktionen av mervärde kan vara tekniker av olika slag, arbetsledare i produktion och transport och organisatörer och ombesörjare av transport och kommunikation (198I, s. 57). Till skillnad från arbetarklassen i denna sektor företräder de också kapitalisterna i uppgiften att "tillägna sig och bestämma användningen av merprodukten" (I98I, s. I5).

I ovanstående uppräkning av vad som ingår i produktionssektorn sägs det inget om tjänster utan det utgör istället en egen sektor i Therborns indelning, i vilken ingår "utförande av tjänster åt andra personer för deras välbefinnande, bekvämlighet eller förströelse, såsom frisering, städning, servering, persontransporter, underhållning osv, tjänstesfären i denna snävare mening (i det följande har persontransporter, av praktiska skäl, sammanslagits med varutransporter)" (198I, s. I7). Han skiljer mellan privata och offentliga tjänstearbetare. Kategorier som ingår i privata tjänster är bland annat köks- och serveringspersonal, samt städare. Kategorier som ingår i offentliga tjänster är bland annat kommunala trädgårdsarbetare, bussförare, brevbärare, städare, fastighetsskötare (I98I, s. 40).

Eftersom tjänstearbetet inte ingår i produktionssektorn så är det uppenbarligen inte produktivt, det vill säga det producerar inget mervärde. Det innebär att Therborns produktionssektor bara består av varuproduktion i den vardagliga betydelsen av begreppet vara, det vill säga som något materiellt påtagligt och avgränsat, ett ting som kan transporteras och säljas vidare. Therborn tycks mena att enbart produktionen av ting kan producera mervärde och vara produktiv för kapitalet. Det stämmer dock inte överens med hur Marx såg på varan och produktivt arbete (20I8a, s. 444): 
Endast den arbetare är produktiv, som producerar mervärde åt kapitalisten eller bidrar till att kapitalet förökas. Om vi tillåter oss att välja ett exempel utanför den materiella produktionens område, kan vi säga att en lärare är en produktiv arbetare, om han inte endast bearbetar barnasinnen utan arbetar ut sig för att berika en företagare. Att denne har placerat sitt kapital i en lärofabrik i stället för en korvfabrik, har ingen betydelse.

Wright hänvisar också till detta citat i sin kritik av Poulantzas från 1977. Även Poulantzas förknippade nämligen produktionen av mervärde med ting. Det var nog en ganska vanlig uppfattning vid denna tid. Therborn försvarade den i sin artikel från 1983 (I983a, s. 42). Han hade dock tur med tajmingen eftersom kapitalet ännu inte hade underordnat sig så mycket tjänsteproduktion och framför allt ingen reproduktion.

Det fanns dock redan då vissa svårigheter med att strikt hålla sig till produktionen av ting. Therborn kände sig uppenbarligen tvungen att räkna in transportarbetarna i den produktiva sfären. För att lyckas med det definierade han cirkulationssektorn som "den verksamhet som enbart består i förmedling och förvaltning av ägande- och nyttjanderättigheter, av köp och försäljning” (198I, s. I7). Därmed räknade han bort till exempel butikspersonal från den produktiva sfären. Här uppstår en knepig genusproblematik. Det i huvudsak manligt dominerade transportarbetet anses vara produktivt, men inte den i huvudsak kvinnligt dominerade butikspersonalen. $\mathrm{Om}$ inte annat så har de senaste decenniernas expansion av köpcentra och stormarknader visat på det orimliga i att hålla fast vid en sådan gränsdragning.

Ta till exempel den stora livsmedelsaffären Hemköp vid Triangeln i Malmö. Där flyttar personalen varor mest hela tiden, in i butiken från lagret, ställer i ordning på hyllorna, guidar kunder om var varorna finns och så vidare. Allt detta kan inte bara betraktas som en transaktion utan måste ses som bruksvärdeproducerande för konsumenterna och produktivt för kapitalet. Detsamma gäller med en hel del av det han kallar tjänstesfären, till exempel många av dagens myriader av restauranger och caféer. Transporter ingår i Therborns produktionssfär, men inte servering. Men det senare måste väl också ses som en transport? Både lastbilschauffören och servitrisen gör ju produkter tillgängliga genom förflyttning. Det blir uppenbart när varan ska förflyttas från Kina till Sverige men måste också 
gälla när den tillagade måltiden ska bäras ut och serveras i restaurangen. Så här skriver Marx om transportarbetet (20I8b, s. 49):

Men det som transportväsendet säljer är själva ortsförändringen, och den åstadkomna nyttoeffekten är oskiljbart förenad med transportprocessen [...] Nyttoeffekten måste därför konsumeras, medan produktionsprocessen pågår. Den är inte knuten till ett nyttoting, som har en självständig tillvaro, och kan därför inte ingå $\mathrm{i}$ cirkulationen som vara, sedan produktionen har avslutats. Men denna nyttoeffekts bytesvärde bestämmes - liksom alla andra varors - genom värdet av de produktionselement (arbetskraft och produktionsmedel) som förbrukas i varan, plus det mervärde, som skapas av de i transportväsendet sysselsatta arbetarnas merarbete.

Vad jag vill ha sagt med detta är att både produktion och cirkulation av varuprodukter (det vill säga ting) såväl som tjänsteproduktion kan vara mervärdeproducerande. Det beror i grunden på att samtliga tre produktionsformer kan producera varor i den abstrakta betydelsen av detta begrepp. I sin mest abstrakta form kan en vara definieras som en kombination av bruks- och bytesvärden. Det inbegriper det som i dagligt tal kallas vara men också en hel del av det som kallas tjänster. Alla bruksvärden som också kan säljas är att betrakta som varor. Det är sedan en förutsättning för att arbetet ska kunna vara produktivt för kapitalet, det vill säga att det ska kunna producera mervärde. All produktion av varor i denna abstrakta mening kan producera mervärde och därmed vara produktivt för kapitalet.

Rent principiellt kan därmed arbete $\mathrm{i}$ alla Therborns fyra sektorer vara mervärdeproducerande och produktivt för kapitalet. Det krävs dock att de kriterier uppfylls som nämns i ett av citaten ovan. De måste vara anställda av kapitalägare, inte ha några maktbefogenheter delegerade till sig av arbetsgivaren och inte ha en anställnings- och arbetssituation som skiljer ut dem från massan av produktiva kroppsarbetare (I98I, s. 27). Historiskt har detta gällt industriarbetare men idag gäller det även många som arbetar inom det som Therborn kallade reproduktionssfären, det vill säga "arbete med att direkt upprätthålla eller frambringa nytt mänskligt liv och grundläggande sociala relationer, såsom nödvändig matlagning, barnuppfostran, utbildning, vård, rättsskipning, allmän förvaltning” (I98I, s. I8). De stora arbetargrupperna i reproduktionssektorn när 
Therborn gjorde sin klassanalys var matlagnings- och serveringspersonal samt sjukvårdsbiträden (I98I, s. 45).

"Kännetecknande för arbetare inom reproduktionssfären är att de inte arbetar efter lönsamhetskriterier" (I98I, s. 20), skrev Therborn i sin bok och så var det helt klart under den tid som hans analys gällde. Så är det inte idag. $\mathrm{Nu}$ för tiden arbetar en betydande del av alla reproduktionsarbetare efter lönsamhetskriterier. De är anställda av kapitalägare, har inte några maktbefogenheter delegerade till sig av arbetsgivaren och har i stort sett samma anställnings- och arbetssituation som andra produktiva kroppsarbetare. De är således mervärdeproducerande och för kapitalet produktiva. Därmed borde de räknas in i produktionssfären. Men vad händer då med produktionssfären? Tidigare var den ganska enhetlig eftersom den i stor utsträckning bestod av tillverkning, det vill säga produktion av ting. Så såg verkligheten ut på den tiden. Nu bör ju en del av tjänste- och reproduktionssfärerna ingå. Ska dessa olika typer av arbeten då utgöra underavdelningar i en mera diversifierad produktionssfär? Eller går det att göra en annan indelning? Hur har Therborn själv gjort i sin senaste klassanalys, nästan 40 år efter den förra?

\section{Vad gjorde Therborn av sitt gamla klassbegrepp i sin nya analys?}

Kapitalet, överheten och alla vi andra från 2018 är en innehållsrik bok. Den är rik på intressant och relevant faktakunskap om dagens svenska klassamhälle, fyndigt framgrävd från en mångfald av olika källor. Dess spektrum av faktakunskap är mycket bredare än i den förra boken från I98I. Jämfört med den förra boken innehåller den senaste boken dock inte så mycket analys och tar oss inte "från det föreställda konkreta till det allt tunnare abstrakta". I linje med denna skillnad är den senaste boken inte heller lika teoretiskt styrd som den förra. Det visar sig bland annat $\mathrm{i}$ att begreppen inte är lika tydligt definierade. Det han ägnade hela sin bok åt 198I ryms nu på mindre än Io sidor.

Därmed inte sagt att den senaste boken saknar teoretisk grund. Snarare handlar det nog om en förskjutning av den teoretiska grunden. Denna förskjutning kommer framför allt till uttryck i en avsaknad av 
uppgift om hur många som producerar mervärde i dagens svenska samhälle. Den uppgiften var central i den förra boken. Det är nog därför den mest anmärkningsvärda skillnaden mellan böckerna. Den kategori som producerar mervärde kallades i boken från 198I "arbetarklassen i snäv mening". Den bestod av alla de arbetare som ingick i det han då kallade produktionssfären.

I Therborns senaste bok finns det inte längre någon produktionssfär i den tidigare betydelsen. Det innebär att det han tidigare kallade arbetarklassen i snäv mening inte längre urskiljs. Vi får inte reda på hur stor den är. Endast den totala andelen anställda inom kapitalismen anges. Andelen löntagare som arbetar för kapital har ökat från 60 procent till 67 procent, I980 jämfört med 2017 (20I8, s. 65). Dessa sägs dock inte ingå i en produktionssfär. Det finns visserligen en tabell i boken med en indelning av arbetarklassen i fyra sfärer, men den kommenteras inte och produktionssfären har nu bytt namn till varuproduktionssfären. Det är en helt annan indelning eftersom den inte grundar sig på förhållandet till mervärdeproduktionen.

Han hänvisar visserligen till "minskningen av antalet arbetare i produktion, transport och lagring av varor, vad jag 198I kallade arbetarklassen i snäv mening” (2018, s. 67). Det var dock inte för att de arbetade med varuprodukter (ting) som han kallade dem arbetarklass i snäv mening utan det var för att de producerade mervärden och därmed var produktiva för kapitalet. Detta gjordes dock vid den tiden så gott som enbart av arbetarklassen i produktion, transport och lagring av varor (ting). Det råkade således sammanfalla. 2018 är det istället bruksvärdets form, det som Marx också kallar naturalformen, som sägs ha motiverat indelningen.

Värdeteorin tycks ha försvunnit i Therborns nya klassanalys. Klasssamhället definieras nu som ett "samhälle uppdelat i ojämlika klasser med olika möjligheter att förverkliga sina liv i nivå med mänsklighetens utveckling" (2018, s. 22). Ojämlikheten har smugit sig in i definitionen och ersatt mervärdet. Det är på grund av ojämlikheten som människor kan delas in i klasser, inte för att vissa producerar mervärde och andra tillägnar sig det. Nu heter det istället: "Klass är alltid en fråga om ojämlikhet, men all ojämlikhet är inte av klasskaraktär" (20I8, s. 22). Det 
stämmer dock inte med den uppfattning som Marx gav uttryck för i Kapitalet. Där beskriver han bytet mellan kapital och arbete som likvärdigt och, som tidigare nämnts, ”alls ingen orätt mot säljaren”. Jag ska återkomma till det men först ta reda på vad Therborn menar med ojämlikhet.

Therborn utvecklar en teori om ojämlikhet i den tidigare boken Ojämlikhet dödar. Med ojämlikhet menar han "en olikhet som bryter not en norm eller ett antagande om en (inomvärldslig) jämlikhet (inte nödvändigtvis uttalad och tydlig)" (2016, s. 50). Det är ett normativt begrepp, till skillnad från merarbete. Det senare kan man tycka både bra och dåligt om. Eller så tycker man ingenting om det. Det har ingen betydelse för dess existens. Ojämlikhet gäller däremot just skillnader mellan bra och dåligt, vilka vi alla i grunden är överens om. Den allmänna norm som enligt Therborn ligger till grund för ojämlikhet $\mathrm{i}$ vår tids samhällen är de mänskliga rättigheterna. Vår tids ojämlikhet kan därmed definieras som "en kränkning av en mänsklig rättighet, en kränkning som förhindrar miljarder människor att fullt ut utvecklas som människor" (20I6, s. 53).

Utifrån denna definition skiljer han mellan olika former av ojämlikhet. Med vital ojämlikhet menar han orättfärdiga skillnader som gäller liv och död. Existentiell ojämlikhet gäller "fördelning av det som gör oss till personer, det vill säga autonomi, värdighet, frihet, rätt att bemötas med respekt och rätt att förverkliga sina möjligheter” (2016, s. 60). Med resursojämlikhet menar han skillnader som gäller förmågan att agera. Dessa tre beskrivs som fundamentala dimensioner av ojämlikhet. De gäller oss som biologiska organismer, personer respektive aktörer. Inget av dem gäller det vi gör. Det innebär ett grundläggande skifte av fokus. Klassanalysen handlar inte längre om processer, det som var centralt I98I, utan om tillstånden, i en bred mening det människor har, det vill säga det som inte var klassanalysens grundfrågor 198I enligt Therborn, nämligen (I98I, s. I3): "Hur mycket har människor av resurser (i status, pengar eller annat) och möjligheter (till utbildning och avancemang)?" Det påminner om Wrights klassbegrepp och den skillnad som han tidigare markerade gentemot detta, till exempel i texten från 1983, verkar han inte längre vilja kännas vid. 
På motsvarande sätt tycks han ha färmat sig från Marx. Som nämnts ovan beskriver inte Marx bytesrelationen mellan kapital och arbete som en ojämlikhet utan tvärtom som en jämlikhet. Dock blir bytesrelationen också en produktionsrelation eftersom lönearbetaren säljer sin arbetskraft till kapitalet. I denna är lönearbetaren formellt sett underordnad. Inte heller denna formella över- och underordningsrelation kan betraktas som en ojämlikhet. Intressantare blir det dock när Marx visar hur den formella underordningen utvecklas till en reell underordning. Genom utbytet mellan lönearbetare och kapitalister införlivas formellt sett det levande arbetet med kapitalet. Det förvandlas därmed reellt sett till en verksamhet som tillhör kapitalet. Den vinstdrivna omvandlingen av arbetsprocessen sätter sina spår i både kropp och själ (Marx 20I8a, s. 295). Lönearbetaren förvandlas till en allt mindre bricka i ett allt större spel.

Kapitalet utvecklas till en alltmer samhällelig produktivkraft. I förhållande till denna samhälleliga produktivkraft står den enskilde arbetaren där ensam med sin arbetskraft och kan inte göra så mycket annat eftersom hen vanligtvis inte äger några produktionsmedel utan bara sin arbetskraft. Hen ingår visserligen också i den samhälleliga produktivkraften men bara under en viss tid och på en viss plats. Och just vid denna tid och på denna plats äger hen inte sin egen arbetskraft, för den har kapitalet köpt. Lönearbetaren kan inte bidra till samhällsutvecklingen annat än som kapitalets egendom. Detta skulle kunna beskrivas som en ojämlikhet eftersom det, i enlighet med Therborns definition, "förhindrar miljarder människor att fullt ut utvecklas som människor" (20I6, s. 53). Det passar dock inte riktigt in i Therborns schema utan kräver nog en uppdelning av hans existentiella ojämlikhet i en kulturell respektive strukturell ojämlikhet (Stigendal 20ı6). Den strukturella ojämlikheten skulle då kunna beskrivas som ett resultat av den reella underordningen.

I Skola för lönsamhet analyserar Majsa Allelin skolans utveckling utifrån distinktionen mellan formell och reell underordning. Hon visar hur den svenska grundskolan genom friskolereformen har kommit att införliva en kapitalistisk rationalitet och omvandlat utbildning till en vara. Det har inneburit att delar av grundskolan nu drivs främst av vinstintressen. Den reella underordning som det har fört med sig kommer bland 
annat till uttryck i en standardisering och pedagogisk likriktning (Allelin 2019, s. I52).

Therborn säger däremot inget om dessa drivkrafter när han i 2018 års klassanalys ska definiera kapitalism, det som var så centralt för honom 198I. Två kännetecken framhålls i 2018 års definition. Kapitalism kännetecknas för det första av en klassuppdelning mellan ägare och arbetare. Denna uppdelning utgör nu en ojämlikhet, det vill säga en orättfärdig skillnad mellan det som olika kategorier har, och grundar sig inte på merarbete, det vill säga det som människor gör. För det andra kännetecknas kapitalism av en "allt dominerande inriktning på ackumulation av kapital, på vinst åt ägarna” (20I8, s. 57). Det säger ingenting om vad som driver denna ackumulation av kapital. Kan det måhända vara sedvänja, kynne eller kultur? Therborn lämnar i Kapitalet, överheten och alla vi andra öppet för olika tolkningar och kan till exempel få en att uppfatta de enskilda individerna som motståndare. Det intrycket stärks av de hårda ord som används; ”Therborn excellerar i sarkasmer och invektiv”, som Bo Rothstein skriver i sin recension av boken (2018).

Det får betydelse för funderingarna på lösningar. Räcker det med att bli av med de personer som sarkasmerna och invektiven riktas mot för att lösa problemen?, kan man undra. Det menar säkert inte Therborn, men han banar knappast väg för den förändring och det avskaffande av klassamhället som han hoppades att hans bok 198I skulle inspirera andra att bidra till (198I, s. I42). Klass sägs visserligen vara en förändringsresurs men "för att begränsa ojämlikheten" (20I8, s. 22). Det är inte ett kvalitativt annorlunda samhälle han verkar se framför sig utan mer en kvantitativ minskning av ojämlikheten.

Den tyngsta drivande kraften i den ekonomiska omvälvning och den skarpa högergir som har skett i Sverige under de senaste decennierna beskrivs av Therborn som "maktförskjutningen inom kapitalismen, från produktivt industrikapital till spekulativt finanskapital" (2018, s. 77). I en artikel från 1983, "Why Some Classes Are More Successful than Others", visar han vilken betydelse denna skillnad kan ha för formeringen av klasserna men då med förankring i värdeteori (1983b). Den förankringen saknas 20I8. Därför klargörs inte heller den viktiga förändring av exploatering som har skett. Varifrån kommer de finansiella vinsterna? 
Det är rubriken på ett kapitel i Cédric Durands bok Fictitious Capital. How Finance is Appropriating Our Future (2017). Durands svar grundar sig på en Marx-inspirerad värdeteori med begreppet fiktivt kapital som central beståndsdel. Fiktivt kapital består av anspråk på värde som ännu inte har producerats. Genom det fiktiva kapitalet sätter man sig i skuld till framtiden. Kanske är det också avsaknaden på värdeteori som gör att Therborn inte nämner skuldsättningen bland orsakerna till det passiva accepterandet av högergiren i politiken under de senaste decennierna (20I8, s. 73). Kanske är det också därför han i slutet av boken inte nämner den enorma ökningen av det fiktiva kapitalet. "Den tilltagande ojämlikhet och det växande ekonomisk-sociala utanförskap vi ser i dag kan mycket väl fortsätta i fyrtio år till” (2018, s. I46). Det tror inte jag. Och ett huvudskäl är just den enorma ökningen av det fiktiva kapitalet som innebär att kapitalismen har förlorat fotfästet i verkligheten, vilket lär komma att straffa oss alla. Ett annat är förstås klimatkrisen. Inte heller denna blir riktigt begriplig utan en teori om kapitalet som lyfter fram dess drivkrafter. Max Koch \& Hubert Buch-Hansen visar i en aktuell artikel hur det kan göras med hjälp av regleringsteorin (2020).

Ett kort svar på avsnittsrubrikens fråga: "Vad gjorde Therborn av sitt gamla klassbegrepp i sin nya analys?", är att han trollade bort det. Som framgår ovan använder Therborn ett annat klassbegrepp 2018 än det han använde 198I. Han säger dock ingenting om skillnaden. Den får man analysera sig fram till. Men jag kan tänka mig ytterligare ett svar på rubrikens fråga. Therborns ambition var kanske inte att uppdatera sin klassanalys utan istället att gräva fram all den faktakunskap som krävs för att det också ska kunna göras en syntes, det vill säga den rika "totalitet med många bestämningar och relationer" som enligt Marx måste följa efter analysen. Detta framgrävande har Therborn i så fall lyckats väldigt bra med. Men då kvarstår det att göra klassanalysen för att med användning av bland annat den empiri som Therborns bok innehåller skapa syntesen. Det senare, syntesen, får göras i ett annat sammanhang (Stigendal 202I). Här avgränsar jag mitt intresse till klassanalysen. Med vilket klassbegrepp skulle en aktuell klassanalys kunna göras? 


\section{Ett behovsprövat klassbegrepp}

Behövs det egentligen ett klassbegrepp? Det beror på vad man menar med klass, det vill säga hur begreppet klass definieras, men också på vilket behov det ska fylla. Det är två frågor; den ena om behovet och den andra om vilket klassbegrepp som kan tillgodose det. Den som bortser från den första frågan, tar behovet för givet och ger sig direkt i kast med att definiera klassbegreppet kan känna sig välförankrad i det jag har kallat värdeteorins ena spår. En risk man då tar är att jämförelsen mellan klassanalyser utifrån olika klassbegrepp kan urarta i en tävling. Den som med sin definition kan räkna in flest $\mathrm{i}$ arbetarklassen vinner.

Så kan det gå om man fokuserar på tillstånden och det som människor har, inte på processerna och det som görs; det vill säga när indelningarna inte är kopplade "till en analys av samhällsutvecklingens drivkrafter och dynamik", som Therborn skrev i sin bok från 198I (s. 13). För det är detta som är klassanalysens mening, tillade han, och jag tänker att han hade så rätt i det. Med den utgångspunkten formulerade Therborn tre frågor. Han kallade dem klassanalysens grundfrågor. De gäller inte vad människor har i olika avseenden, till exempel resurser eller möjligheter, utan vad de gör.

Therborns frågor från 198I är enligt min uppfattning lika relevanta idag. Det behövs säkert många begrepp för att besvara dessa frågor men ett klassbegrepp är särskilt viktigt. Det är just därför det behövs. Dess bruksvärde beror på hur väl det kan bidra till att besvara klassanalysens grundfrågor och därigenom kopplas till en analys av samhällsutvecklingens drivkrafter och dynamik. Jag ska anknyta till Therborns tre frågor från 198I och i ljuset av dem, genom en allt vidare spiral, skapa en allt mer konkret men samtidigt komplex definition av begreppet klass. Dessutom ska jag lägga till ytterligare en - en fjärde fråga.

\section{Vilka är sambällets ekonomiska drivkrafter?}

Therborns första fråga: "Vilka är det samhälles ekonomiska drivkrafter som människorna lever i?" Drivkrafterna skiljer sig mellan olika produktionssätt. Jag har i den här artikeln ägnat nästan allt utrymme åt det kapitalistiska produktionssättet. Det finns dock även andra. I sin bok 
från 198I skriver Therborn också en hel del om det produktionssätt som Marx kallar enkel varuproduktion. De som driver detta produktionssätt är ofta egna företagare men de kan också ha några anställda och samtidigt arbeta själv i verksamheten. Den kan gälla produktion av såväl ting som tjänster. Huvudsyftet är inte vinsten utan att verksamheten ska gå runt, "med en inriktning snarare på den egna konsumtionen och den egna självständighetens bevarande", som Therborn beskrev det 198I (s. I6; se även Elson 1979, s. I26).

Ett annat produktionssätt skymtar fram i boken Klassamhällets förändring där Ahrne et al. (1985) skilde ut den offentliga sektorn och betonade dess särart i jämförelse med den kapitalistiska produktionen. En hel del av den offentliga sektorn har sedan dess stöpts om i enlighet med New Public Management men, med Therborns ord från 198I (s. 50) som fortfarande gäller: "det betalda arbetet har inte till (primär) uppgift att öka den offentliga arbetsgivarens inkomster utan att bereda trygghet och bekvämlighet mm åt medborgarna och/eller de styrande.” Till skillnad från kapitalismen kan den offentliga produktionen av till exempel utbildning, vård och omsorg därför inte karakteriseras som vinstdriven utan som behovsdriven.

Därutöver kan man fundera över om inte civilsamhället utgör ett eget produktionssätt. Det kan i så fall kallas idé-drivet. De går således att urskilja minst fyra produktionssätt i dagens svenska samhälle, vilka skiljer sig med avseende på just drivkrafter; nämligen det vinstdrivna (kapitalism), det gå-runt-drivna (enkel varuproduktion/småföretagsamhet), det behovsdrivna (offentlig sektor) och det idédrivna (föreningsliv).

\section{Vad gör människor i denna samhällsprocess?}

Svaret på Therborns andra fråga - "Vad gör de i denna samhällsprocess?” - beror därför på i vilket produktionssätt de ingår. Människor producerar nämligen inte bara något naturligt (till exempel livsmedel, bilar, banomsorg, mäkleri, socialförsäkringar) utan de reproducerar samtidigt också särskilda samhällsförhållanden, det vill säga relationer och drivkraft som hör till produktionssättet. Hur stor andel av den förvärvsarbetande befolkningen som ingår i respektive produktionssätt bidrar därmed också till att besvara den första frågan, den om samhällets 
ekonomiska drivkrafter. Svaret ger besked om genomslaget för de olika typerna av drivkrafter.

I avsnitt 4 såg vi hur det marxistiska klassbegreppet tar sin utgångspunkt i definitionen av kapital som en social relation. Här på denna högsta abstraktionsnivå kan de två huvudklasserna definieras, arbetare och kapitalister. Båda definieras utifrån vad de gör, inte beroende på vad de har. Mer specifikt gäller görandet i vilken utsträckning de producerar respektive tillägnar sig mervärdet. Därmed faller också många utanför eftersom de inte tillhör det kapitalistiska produktionssättet. Dessa kan istället kategoriseras som till exempel enkla varuproducenter eller behovsproducenter. I 198I års klassanalys använde sig Therborn av begreppen arbetarklass i snäv respektive bred mening och det är fortfarande användbara begrepp (se avsnitt 6).

Indelningen i arbetare och kapitalister är dock ganska grov. Som Therborn visar i sin bok från 198I har det vuxit fram en lång rad med kategorier som inte är kapitalister men heller inte arbetare. Han kallar dem för mellanskikt (se avsnitt 6) och detta begrepp hjälper oss att göra analysen lite konkretare men samtidigt då också komplexare. Begreppet mellanskikt äger sin giltighet inom flera produktionssätt, men då med lite olika definitioner.

Vill vi sedan gå vidare inom det kapitalistiska produktionssättet kan vi bli ytterligare ett snäpp konkretare genom att urskilja olika kategorier i kapitalets cirkulationsprocess. Således finns det grund för att till exempel penning-, industri- och handelskapitalister kan ha lite olika intressen. Det märks tydligt nu för tiden då penningkapitalisterna satsar merparten av sitt kapital på berövande av befintliga värden och inte på att bidra till producerandet av nya; "wealth extraction" som Andrew Sayer kallar det (20I5, s. 34ff). Med inspiration av David Harvey (20I0) kan vi betrakta det som en särskild form av kapitalackumulation, kallad berövandeackumulation (accumulation by dispossession). Det ingår i den finansdrivna kapitalackumulation som har kommit att dominera under de senaste decennierna. Eftersom den har utvecklats till en ackumulationsregim och dessutom kopplats till ett särskilt regleringssätt kan den också betraktas som en finansdriven tillväxtmodell och som sådan jämföras med fordismen. 
Jag ska inte stapla begreppen på varandra utan nöja mig med ovanstående som exempel på hur allt fler begrepp kan behöva införlivas när vi färdas från abstrakt till konkret och samtidigt från enkelt till komplext. Därutöver måste så klart begreppen kön och etnicitet också införlivas i syntesen. Det vi bör sträva efter är att skapa en rik totalitet av begrepp med många bestämningar och relationer, det som Marx också kallade det tänkt konkreta. Det utgör därmed svar på Therborns andra fråga om vad människor gör i denna samhällsprocess.

\section{Struktur och aktör}

Det människor gör, det gör de genom olika former och det är dessa formers logik som begreppen ska hjälpa oss att förstå. Det anknyter till den på 1980-talet livligt debatterade frågan om struktur och aktör. Under de senaste decennierna har denna fråga fallit lite i skymundan. Det hänger förmodligen ihop med fokusförflyttningen från det som människor gör till det som de har, det vill säga det som diskussionerna om ojämlikhet gäller. Ett av mina huvudbudskap i denna artikel är att fokus måste flytta tillbaka till det som människor gör. Därmed blir frågan om relationen mellan struktur och aktör återigen aktuell.

Det mest intressanta svaret på den frågan, enligt min uppfattning, har Bob Jessop utvecklat genom det han kallar för det strategiskt-relationella förhållningssättet (strategic-relational approach, SRA).5 Precis som den mer kända och inflytelserika struktureringsteorin, förknippad med framför allt Anthony Giddens (I984; se även Danermark et al. 20I8), tar SRA sin utgångspunkt i att alla sociala strukturer måste göras. För det krävs det aktörer, individuella eller kollektiva. När de agerar så sker det i mer eller mindre strukturerade sociala sammanhang. De kan därmed inte göra vad som helst. Men deras agerande är inte heller helt förutbestämt.

Det senare hävdar däremot struktureringsteorin. Giddens drar sina slutsatser om såväl strukturer som aktörer genom att analysera dem var för sig. De analyseras inte som potentialer utan så som de är aktualiserade vid ett visst tillfälle och av de aktuella aktörerna. Struktureringsteorin begränsar således sin analys till den nivå som kritisk realism kallar

5. Se t ex Jessop 2005 för ett teoretiskt fördjupat klargörande av vad detta innebär och Jessop 2008 för en historieskrivning av hur det har utvecklats. 
det aktuella men utan att i sina slutsatser kunna beakta vad det är som aktualiseras. Utifrån kritisk realism kan man därför hävda att Giddens och struktureringsteorin saknar ett ontologiskt djup.

Det saknar däremot inte SRA. Med en uttrycklig förankring i kritisk realism uppmanar SRA till analyser av såväl potentialerna som aktualiseringarna av dem, precis som för övrigt Marx gjorde i tillvägagångssättet med analys och syntes, den form av slutledning som inom kritisk realism kallas retroduktion. En social struktur, till exempel den på en arbetsplats, existerar som aktualitet när den görs men också som potential genom sina beståndsdelar, utformade för att kunna utgöra den sociala strukturen när de genom en viss praktik sätts i samband med varandra. Det gäller till exempel läraren som ska undervisa studenter i ett visst ämne och som har fătt sin potential betygsatt genom examination. Det gäller också till exempel lokalen som undervisningen ska äga rum i och vars ändamålsenlighet har prövats på olika sätt. Eftersom dessa beståndsdelar är utformade i förhållande till varandra existerar även sambandet mellan dem som potential. Det möjliggör analyser av hur dessa samband kan vara präglade av till exempel olika produktionssätt och vad övergången från en behovsdriven till vinstdriven undervisning kan innebära och få för konsekvenser. Hur beståndsdelarna sedan fogas samman genom aktualiseringens praktik är en annan sak och som till exempel kan bero på lärarens individuella skicklighet eller pedagogik.

En social struktur kan därmed göras på lite olika sätt. Dess inneboende begränsningar och möjligheter är inte helt förutbestämda, som Giddens påstår, utan de beror också på den aktör som gör dem. Det innebär att det finns ett handlingsutrymme (Stigendal 2018). Det vet varje fotbollstränare. Frågan är om man inte som fotbollstränare måste vara en kritisk realist i praktiken för att kunna lyckas. ${ }^{6}$ Det går att spela samma roll på lite olika sätt, till exempel utifrån att man skaffar sig mer kunskap. Får man till exempel klart för sig att ens praktik i en viss roll bidrar till ojämlikheten kanske man vill försöka utnyttja sitt handlingsutrymme och agera lite annorlunda, utan att för den skull falla utanför rollen.

6. Påpekat av min son Johan, utbildad fotbollstränare men för tillfället inte verksam som sådan. 


\section{Vad kan människor förväntas göra?}

Det strategiskt-relationella förhållningssättet kan också bidra till att besvara Therborns tredje fråga: "Vad kan de förväntas göra (bevara eller söka förändra det bestående, och i så fall i vilken riktning)?" Therborn besvarade själv denna fråga i sin artikel från 1983, "Why Some Classes Are More Successful than Others", med hjälp av begrepp som inneboende klasstyrka och hegemonisk klasskapacitet. För arbetarklassens del framhöll han kollektiviteten som dess inneboende styrka. Storskalig industriproduktion tenderar att befrämja en hög grad av arbetarklasskollektivitet. Det gör däremot inte kapital som ackumuleras genom till exempel bankverksamhet (1983b, s. 42).

I Katalys' klassprojekt gjorde Gunnar Olofsson en liknande analys av hur allt fler inom välfärdsprofessionerna får allt mer gemensamt som en följd av besparingar, ökad arbetsintensitet, usla arbetstider och försämrade lönevillkor. Allt detta kan därigenom utgöra en ny bas för motstånd (Olofsson 2018, s. 9; Suhonen et al. 202I). En sådan klassanalys bidrar onekligen med ett svar på Therborns tredje fråga. Jag menar att det strategiskt-relationella förhållningssättet (SRA) möjliggör ytterligare ett svar genom att lyfta fram handlingsutrymmena. Kan kunskapen om klassamhället spridas bland de välfärdsprofessionella skulle det kunna inspirera dessa aktörer till att utnyttja sina handlingsutrymmen bättre.

\section{Vad gör det med dem?}

Jag saknar en fråga i Therborns bok från 1981. Den kan formuleras så här: När människor gör det de gör, vad gör det då med dem? Genom det vi gör så gör vi oss samtidigt till dem vi är och blir. Produktionen skapar inte bara konsumtionens objekt, som Marx skriver i Inledning till kritiken av den politiska ekonomin, utan också dess subjekt, det vill säga konsumenten. Produktionen gör oss till exempel hungriga men beroende på hur vi producerar, på vilka villkor och genom vilka relationer till andra gör produktionen oss hungriga på ett visst sätt. "Hunger är hunger, men en hunger som tillfredsställs med kokt kött, som förtärs med kniv och gaffel, är en annan hunger än den som tillfredsställs med rått kött, som konsumeras med fingrar, naglar och tänder" (Marx \& Engels 1975, s. 28). 
Det får sin särskilda betydelse i kapitalistiska produktionsförhållanden där underordningen tenderar att inte bara vara formell utan också bli reell. Som tidigare nämnts innebär detta att lönearbetaren både kroppsligen och själsligen formas till att bli en del av kapitalet och kan kanske efterhand inte göra mycket annat än att berika det. Formellt sett möts lönearbetet och kapitalet som två oberoende och likvärdiga varuägare. Men just genom att den ene säljer sitt eget skinn, som Marx skriver, kan hen inte vänta sig annat än att fă det garvat av den som köper det (Marx 20I8a, s. I52). Det är en viktig insikt att använda i analysen av det som brukar kallas vinster i välfärden. När människor arbetar i vinstdrivna verksamheter så gör det något annat med dem än om verksamheten är behovsdriven. I den vinstdrivna verksamheten sätter deras eget producerande av arbetsvärden press på dem att bli en del av kapitalet. Det kan bara ett klassbegrepp med förankring i värdeteorins andra spår hjälpa oss att förstå. Det utgör dess bruksvärde att kunna bidra till svaren på dessa klassanalysens grundläggande frågor.

\section{Klassanalysens framtidsutsikter}

För att kunna göra en klassanalys krävs det klassbegrepp. Det räcker inte med själva ordet klass (signifier) och det är inte heller möjligt. Ord är knutna till en innebörd (signified), något vi tänker på när vi hör och använder dem. Innebörden kan vara mer eller mindre genomtänkt men är ändå styrande för i vilka banor vi tänker och vad vi intresserar oss för. Därför kan det vara viktigt att tänka igenom vad vi menar med ett visst ord. Det är särskilt viktigt när man ska göra en klassanalys. För att kunna veta vad vi ska analysera måste ordet klass definieras som begrepp.

Det har jag gjort i denna artikel. Och jag har gjort det mot bakgrund av ett behov. I artikeln har jag som behov föreslagit en användning av de tre grundfrågor som Göran Therborn formulerade i sin klassbok från 198I. Jag har också lagt till en fjärde fråga. Det behövs ett klassbegrepp som kan besvara dessa fyra frågor. I förhållande till detta behov får klassbegreppet också ett särskilt värde, nämligen ett bruksvärde. Och det är just frågan om vad klassbegreppet har för bruksvärde som jag enligt artikelns titel har åtagit mig att besvara. Det är så som artikeltiteln ska upp- 
fattas. Den gäller inte heller vilket klassbegrepp som helst utan det som har sin förankring i värdeteori. Vid ett första påseende känns det igen på sitt intresse för vad människor gör.

Det vanliga har dock blivit en inriktning på vad människor har. Det framgår av Wrights starka ställning som inspiratör. Det framgår också av Therborns senaste bok. I jämförelse med klassanalysen från I98I har han rört sig från en fokusering på det som människor gör till det som de har. Det har sin bakgrund i en annan tolkning av Marx’ värdeteori, ett spår som innebar att man övergav denna värdeteori.

Den tolkning av klassbegreppet som jag vill propagera för har dessvärre hamnat i skymundan och nämns överhuvudtaget inte i texter om klassbegreppet som har publicerats på senare år (se t ex Hörnqvist 2016; Svallfors 20I6). Det finns dock lysande undantag. Bland dem vill jag nämna två nyligen utkomna doktorsavhandlingar, Majsa Allelins om eleverna i den marknadsanpassade skolan (2019) och Johan Alfonssons om behovsanställdas villkor (2020). Båda förankrar sig i Marx’ värdeteori och båda ger uttryck för en tolkning som ligger i linje med det som här har kallats det andra spåret. ${ }^{7}$

Internationellt finns det gott om företrädare för en liknande tolkning. Jag har nämnt flera i artikeln, till exempel Jessop, Sum, Heinrich och Durand. En annan är David Harvey som härom året publicerade en artikel i ämnet där han också hänvisar till Diane Elsons "seminal article" från I979 (Harvey 20I8). I en nyligen utkommen artikel säger han också bestämt ifrån om att Marx' värdeteori inte är en arbetsvärdeteori: "Det är snarare en teori om de processer genom vilka kapitalet styr över arbetarklassens liv och arbete" (Harvey 2020, s. I08). Det andra spårets tolkning av värdeteorin intresserar sig således inte främst för tillstånden, utan för processerna och det som människor gör. Det gäller dock inte vilket görande som helst utan framför allt produktionen respektive tillägnandet av mervärdet.

Framtidsutsikterna för klassanalysen beror på i vilken utsträckning ett sådant klassbegrepp med förankring i värdeteorin kommer till använd-

7. Den som vill veta mer om vilken betydelse övergången från tillstånden till processerna, från havandet till görandet hade för Marx kan ha stor glädje av att läsa en annan aktuell bok, nämligen Sven-Eric Liedmans bok om Marx, särskilt de avsnitt som handlar om Feuerbach-teserna. Liedman 2015. 
ning. För att bara ge några exempel på dess bruksvärde kan en klassanalys som använder sig av detta klassbegrepp ge mått på genomslaget för de olika produktionssätten. Det kan därmed också visa på hur präglad den totala ekonomin är av olika drivkrafter. Vi kan få reda på hur många som producerar mervärde och i vilka verksamheter samt i vilken utsträckning den svenska kapitalismen är värdeproducerande respektive värdeextraherande. En sådan klassanalys kan bidra till att förklara hur den finansdrivna tillväxtmodellen fungerar i Sverige. Det möjliggör utvecklingen av en rik syntes som kan användas för att säga ganska mycket om vad människor i olika roller har för handlingsutrymmen, vad de kan förväntas göra och vad deras särskilda göranden gör med dem.

Genom att göra en klassanalys utifrån ett sådant klassbegrepp med förankring i värdeteori kan vi säga så mycket mer om inte bara de olika klasskategorierna utan också om de större sammanhang som dessa kategorier ingår i. Sådana klassanalyser behövs, inte främst för att dela in människor i olika kategorier som om det vore ett självändamål, utan som bidrag till förklaringarna av vår tids ödesfrågor, framför allt klimatet men också ojämlikheten, och vad man kan göra åt dem.

\section{Referenser}

Aglietta, Michel (1987). A Theory of Capitalist Regulation. The US Experience. London: Verso (1976)

Ahrne, Göran, Ekerwald, Hedvig \& Leiulfsrud, Håkon (1985). Klassambällets förändring. Lund: Arkiv förlag, faksimilutgåva (2018)

Ahrne, Göran, Stöber, Niels \& Thaning, Max (2018). Klasstrukturen i Sverige. Struktur, klass och inkomster: Kontinuitet och förändring 1985-2015. Rapport 20 i projektet "Klass i Sverige", Katalys - institutet för facklig idéutveckling

Alfonsson, Johan (2020). Alienation och arbete. Unga behovsanställdas villkor i den flexibla kapitalismen. Lund: Arkiv förlag

Allelin, Majsa (2019). Skola för lönsamhet. Om elevers marknadsanpassade villkor och vardag. Lund: Arkiv förlag

Brante, Thomas (1997). "Kausal realism och sociologi". Sociologisk forskning I-2

Burawoy, Michael (2020). "A Tale of Two Marxisms". New Left Review I2I

Danermark, Berth, Ekström, Mats \& Karlsson, Jan Ch. (2018). Att förklara sambället. Tredje upplagan. Lund: Studentlitteratur

Durand, Cédric (20I7). Fictitious Capital. How Finance is Appropriating Our Future. London: Verso 
Elson, Diane (1979). "The Value Theory of Labour". I Elson, Diane (red.). Value. The Representation of Labour in Capitalism. London: CSE Books

Giddens, Anthony (1984). The Constitution of Society. Outline of the Theory of Structuration. Cornwell: Polity Press

Gramsci, Antonio (197I). Selections from the Prison Notebooks. Oxford: Lawrence and Wishart

Harvey, David (2010). The Enigma of Capital. And the Crises of Capitalism. London: Profile Books

Harvey, David (2018). "Marx's Refusal of the Labour Theory of Value".

http://davidharvey.org/2018/03/marxs-refusal-of-the-labour-theory-of-value-bydavid-harvey/ (2I april 202I)

Harvey, David (2020). "Value in Motion". New Left Review I26

Heinrich, Michael (2008). "Monetär värdeteori - pengar och kriser hos Marx". Fronesis 28

Heinrich, Michael (2013). Introduktion till de tre volymerna av Marx Kapitalet. Hägersten: Tankekraft

Hörnqvist, Magnus (2016). Klass. Stockholm: Liber

Jessop, Bob (2002). The Future of the Capitalist State. Cambridge: Polity Press

Jessop, Bob (2005). "Critical Realism and the Strategic-Relational Approach". New Formations 56

Jessop, Bob (2008). State Power. A Strategic-Relational Approach. Cambridge: Polity Press

Jessop, Bob \& Sum, Ngai-Ling (2006). Beyond the Regulation Approach. Putting Capitalist Economies in their Place. Norfolk: Edward Elgar

Koch, Max \& Buch-Hansen, Hubert (2020). "In Search of a Political Economy of the Postgrowth Era". Globalizations. https://doi.org/IO.I080/I4747731.2020.1807837

Liedman, Sven-Eric (2006). Stenarna i själen. Form och materia frän antiken till idag. Stockholm: Albert Bonniers

Liedman, Sven-Eric (20II). Hets! En bok om skolan. Falun: Albert Bonniers

Liedman, Sven-Eric (2015). Karl Marx. En biografi. Stockholm: Albert Bonniers

Marx, Karl (20I8a). Kapitalet. Första boken. Kapitalets produktionsprocess. Lund: Arkiv förlag (I867)

Marx, Karl (2018b). Kapitalet. Andra boken. Kapitalets cirkulationsprocess. Lund: Arkiv förlag (I885)

Marx, Karl \& Engels, Friedrich (1975). Ekonomiska skrifter. Skrifter i urval. Staffanstorp: Bo Cavefors

Olofsson, Gunnar (2018). Professionerna, mellanskikten och klassanalysen. Rapport 13 i projektet "Klass i Sverige", Katalys - institutet för facklig idéutveckling

Pijl, Kees van der (1984). The Making of an Atlantic Ruling Class. London: Verso

Ramsay, Anders (2008). "Marx? Vilken Marx". Fronesis 28

Ritzer, George (red.) (2005). Encyclopedia of Social Theory. Thousand Oaks: Sage Publications

Rothstein, Bo (2018). "Therborn övertygar om den ekonomiska ojämlikheten”. Göteborgsposten, 6 september. https://www.gp.se/kultur/kultur/therborn\%C3\%B6vertygar-om-den-ekonomiska-oj\%C3\%A4mlikheten-I.8076723 
Sayer, Andrew (2015). Why we Can't Afford the Rich. Bristol: Policy Press

Smith, Adam (2008). Wealth of Nations. Oxford: Oxford University Press (1776)

Stigendal, Mikael (20I0). Kapital. Stockholm: Liber

Stigendal, Mikael (2016). Samhällsgränser. Ojämlikhetens orsaker och framtidsmöjligheterna i en storstad som Malmö. Stockholm: Liber

Stigendal, Mikael (2018). Combatting the Causes of Inequality Affecting Young People Across Europe. Croydon: Routledge

Stigendal, Mikael (202I). "En fråga om klass i framtidsstaden Malmö”. I Suhonen, Daniel, Therborn, Göran \& Weithz, Jesper (red.). Klass i Sverige. Ojämlikheten, makten och politiken i det 2I:a århundradet. Lund: Arkiv förlag

Stigendal, Mikael \& Novy, Andreas (2018). "Founding Transdisciplinary Knowledge Production in Critical Realism: Implications and Benefits". Journal of Critical Realism 17:3, 203-220. https://doi.org/I0.1080/14767430.2018.151456I

Suhonen, Daniel, Therborn, Göran \& Weithz, Jesper (red.) (202I). Klass i Sverige. Ojämlikheten, makten och politiken i det 2I: a århundradet. Lund: Arkiv förlag

Sum, Ngai-Ling \& Jessop, Bob (2013). Towards a Cultural Political Economy. Putting Culture in its Place in Political Economy. Cheltenham: Edward Elgar

Svallfors, Stefan (20I6). "Klass". I Edling, Christofer \& Liljeros, Fredrik (red.). Ett delat samhälle. Makt, intersektionalitet och social skiktning. Andra reviderade och utökade upplagan. Stockholm: Liber

Therborn, Göran (198I). Klasstrukturen i Sverige 1930-1980. Lund: Arkiv förlag, faksimilutgåva (20I8)

Therborn, Göran (1983a). "Den nymarxistiska klassanalysens uppkomst och problem". Häften för Kritiska Studier 2

Therborn, Göran (1983b). "Why Some Classes Are More Successful than Others". New Left Review 138

Therborn, Göran (2016). Ojämlikhet dödar. Lund: Arkiv förlag

Therborn, Göran (2018). Kapitalet, överheten och alla vi andra. Klassambället i Sverige det rådande och det kommande. Lund: Arkiv förlag

Wright, Erik Olin (I977). ”Klasser och klassgränser i utvecklade kapitalistiska samhällen. Del i: En kritik av Poulantzas". Zenit 53

Wright, Erik Olin (1978). ”Klasser och klassgränser i utvecklade kapitalistiska samhällen. Del 2: Ett nytt sätt att betrakta klassgränser". Zenit 54

Wright, Erik Olin (1979). "The Value Controversy and Social Research". New Left Review II6

Wright, Erik Olin (2015). Understanding Class. London: Verso 


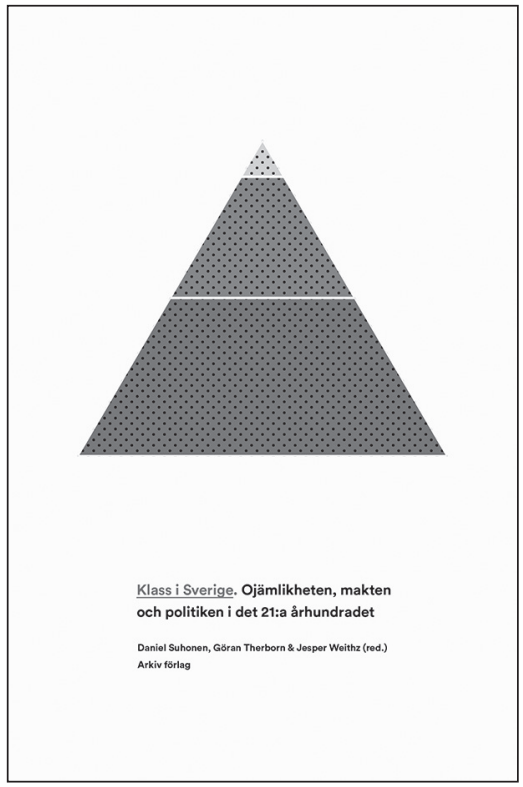

\section{Klass i Sverige Ojämlikheten, makten och politiken i det 21:a århundradet}

Daniel Suhonen, Göran Therborn \& Jesper Weithz (red.)

Det fackliga idéinstitutet Katalys sammanställning av hela sitt omfattande klassprojekt.

752 sidor klass- och samhällsanalys med studiehandledning och extra allt.

"Efter år av flum, associationer och fördomar i diskussionen om klass, har vi äntligen här en solid utgångspunkt. Av 640 sidor är det knappt någon som inte ger en ny insikt. Det är en otrolig gärning av Katalys att presentera den samlade spetsforskningen på detta lättfattliga sätt, med förslag i slutet för den som vill starta en studiecirkel. Jag skulle inte bli förvånad om vi redan här har årets bok."

- Kajsa Ekis Ekman i Aftonbladet

\section{"Läs mer om boken på www.arkiv.nu»}




\section{KLASSISK KLASS- FORSKNING I ÅTERUTGIVNING}

GÖRAN THERBORN

Klasstrukturen i Sverige 1930-1980. Arbete, kapital, stat och patriarkat

I78 sidor

Therborns klassiska arbete om den svenska klasstrukturens utveckling under välfärdsepoken publicerades ursprungligen 1981. Den finns sedan 2018 åter tillgänglig i faksimilutgåva som både gratis e-bok och tryckt bok att köpa.

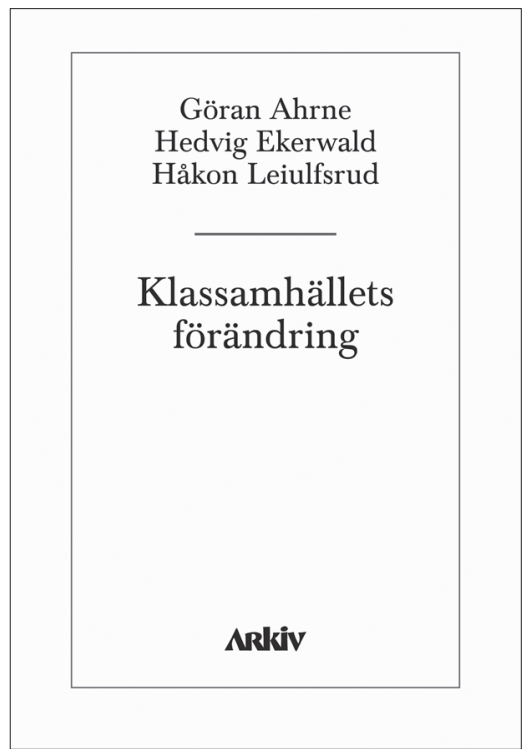

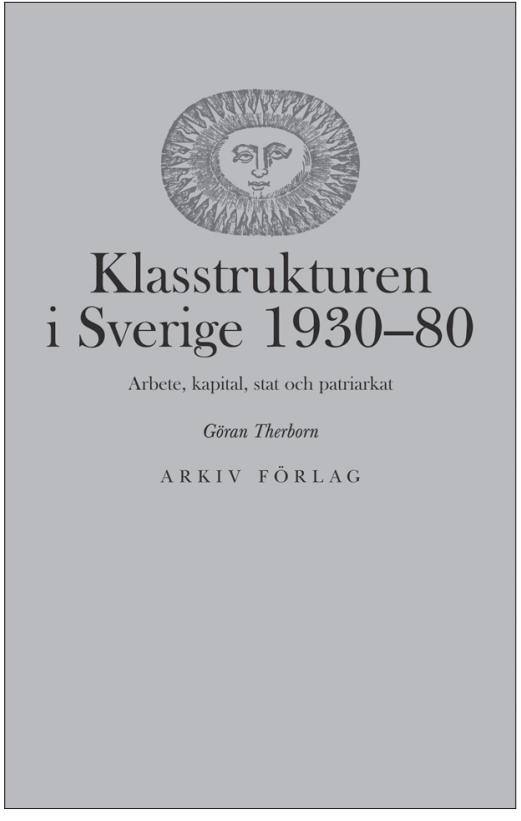

\section{SAMARBETE MED IDÉINSTITUTET KATALYS}

AHRNE, EKERWALD \& LEIULFSRUD Klassambällets förändring I30 sidor

Denna lättillgängliga och inflytelserika klassanalys gavs ursprungligen ut 1985. 2018 års faksimilutgåva återger den fjärde, utvidgade upplagans text från 1995 och finns som både gratis e-bok och tryckt bok att köpa. 